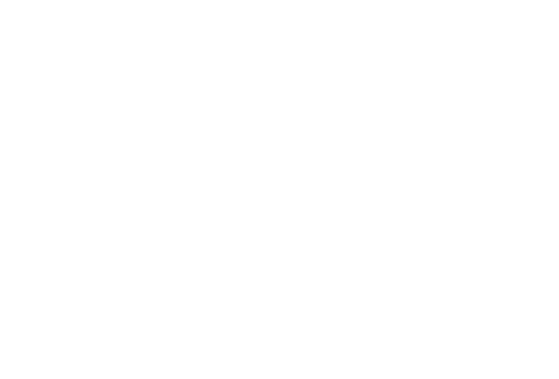

Annu. Rev. Earth Planet. Sci. 2010. 38:439-66

First published online as a Review in Advance on February 24, 2010

The Annual Review of Earth and Planetary Sciences is online at earth.annualreviews.org

This article's doi:

10.1146/annurev-earth-040809-152333

Copyright (c) 2010 by Annual Reviews. All rights reserved

0084-6597/10/0530-0439\$20.00

\title{
Length and Timescales of Rift Faulting and Magma Intrusion: The Afar Rifting Cycle from 2005 to Present
}

\section{Cynthia Ebinger, ${ }^{1}$ Atalay Ayele,,${ }^{2,3}$ Derek Keir, ${ }^{3}$ Julie Rowland, ${ }^{4}$ Gezahegn Yirgu, ${ }^{5}$ Tim Wright, ${ }^{3}$ Manahloh Belachew, ${ }^{1,2}$ and Ian Hamling ${ }^{3}$}

\author{
${ }^{1}$ Department of Earth and Environmental Sciences, University of Rochester, Rochester, \\ New York 14627; email: ebinger@earth.rochester.edu \\ ${ }^{2}$ Institute of Geophysics, Space Sciences, and Astronomy, Addis Ababa University, Addis Ababa, \\ Ethiopia \\ ${ }^{3}$ School of Earth and Environment, University of Leeds, Leeds LS29JT, United Kingdom \\ ${ }^{4}$ School of Environment, Auckland University, Auckland 1142, New Zealand \\ ${ }^{5}$ Department of Earth Sciences, Addis Ababa University, Addis Ababa, Ethiopia
}

\section{Key Words}

dike propagation, magmatic margin, extensional tectonics

\begin{abstract}
Although fault and magmatic processes have achieved plate spreading at mid-ocean ridges throughout Earth's history, discrete rifting episodes have rarely been observed. This paper synthesizes ongoing seismic, structural, space-based geodetic, and petrologic studies from the subaerial Red Sea rift in Ethiopia where a major rifting episode commenced in September 2005. Our aims are to determine the length and timescales of magmatism and faulting, the partitioning of strain between faulting and magmatism, and their implications for the maintenance of along-axis segmentation. Most of the magma for the initial and subsequent 12 intrusions was sourced from the center of the Dabbahu-Manda Hararo rift segment. Strain is accommodated primarily by axial dike intrusions fed from mid-segment magma chamber(s). These findings show that episodic (approximate century interval), rapid opening of discrete rift segments is the primary mechanism of plate boundary deformation. The scale $(\sim 65 \mathrm{~km} \times 8 \mathrm{~km})$ and intensity of crustal deformation $(\sim 6 \mathrm{~m})$, as well as the volume of intrusive and extrusive magmatism $\left(>3 \mathrm{~km}^{3}\right)$, provokes a re-evaluation of seismic and volcanic hazards in subaerial rift zones.
\end{abstract}




\section{INTRODUCTION}

More than two-thirds of Earth's outer shell is oceanic lithosphere generated by decompression and partial melting of upwelling mantle rocks beneath mid-ocean ridges. Batches of molten mantle rock (basalt) rise into cracks and fractures to form long, thin vertical sheets of new crust (dikes) that stall and freeze within frozen dikes or, more infrequently, feed surface eruptions of basalt (e.g., Delaney et al. 1998, Rubin \& Pollard 1988). Dikes serve to transport melt that has percolated upward from mantle source zones (e.g., Kelemen et al. 1997) and has accumulated in magma chambers or thin horizontal magma sheets (sills) within or beneath the crust (e.g., Rubin 1995, Singh et al. 2006, Canales et al. 2006). The denser melt residue (peridotite) forms the lithospheric mantle. Dikes and faults together accommodate plate boundary separation within the crust.

Oceanic rift systems show a regular along-axis bathymetric, structural, and magmatic segmentation at a $\sim 50-\mathrm{km}$ length scale, with thicker, more buoyant crust beneath topographically higher segment centers (e.g., Macdonald et al. 1998, Lin et al. 1990). The temporal and spatial patterns of faulting and magmatism maintain the along-axis morphology of mid-ocean ridges from the onset of seafloor spreading, as seen in the Afar rifting episode from 2005 to the present outlined below. The production, storage, and eruption of magma shape the structure and morphology of the plate boundary, and the buoyancy force of the magma adds to the tectonic forces driving plate divergence (e.g., Buck 2004, Behn et al. 2006). Fluids and heat from magma-filled cracks, dikes, and sills as well as long-lived magma chambers modify the physical properties of the rocks they intrude, temporarily altering the way they respond to tectonic forces (e.g., Holtzman et al. 2003, Evans et al. 2004). Hence, the length and timescales of the magma intrusion process are fundamental to our understanding of lithospheric deformation within rift zones.

Our knowledge of the rates and length scales of fault and magmatic processes is deduced largely from the time-averaged product (oceanic crust and mantle lithosphere remotely imaged by geophysical methods or submersible snapshots) or from dredged and drilled rock samples from active and ancient ridge systems (e.g., Macdonald et al. 1998, Van Avendonk et al. 2001, Bonatti et al. 2003). Despite the widespread occurrence of faults and dikes, only a few episodes of dike intrusion with or without faulting have been detected on submarine and subaerial mid-ocean ridges. The repetition times of ridge magmatism are poorly constrained by difficulties dating young basalts and the short time period of submarine monitoring. Hence, the distribution of plate boundary strain in space and time is poorly understood, as is the partitioning of strain between faulting and magmatism during discrete rifting episodes (e.g., Figure 1).

Rifting episodes along the subaerial Mid-Atlantic Ridge in Iceland (1975-1984) (e.g., Bjornsson et al. 1977, Sigmundsson 2006), the Gulf of Aden Ridge in Afar (1978-79) (Abdallah et al. 1979), and submarine segments of the East Pacific Rise (2005-6) (e.g., Tolstoy et al. 2006, Dziak et al. 2009), Juan de Fuca Ridge (e.g., Fox et al. 2001, Dziak et al. 2007) and Mid-Atlantic Ridge (e.g., Tolstoy et al. 2001, Dziak et al. 2004) provide rare glimpses of magma intrusion and extrusion processes at mid-ocean ridges. Dike-involved rifting episodes also occur in continental rift zones with much thicker, colder lithosphere; faulting, dike intrusion, and a volcanic eruption occurred in the Natron basin, Tanzania from 2007 to 2008 (e.g., Calais et al. 2008). During the 9-year-long Iceland episode, 20 dike intrusions, including fissural eruptions, propagated up to $40 \mathrm{~km}$ along the rift axis from the Krafla magma chamber near the segment center (e.g., Einarsson \& Brandsdóttir 1980, Buck et al. 2006). Extension by dike intrusion and faulting was followed by a decadal-scale relaxation transient that was larger than the time-averaged plate divergence (e.g., Heki et al. 1993, Hofton \& Foulger 1996), a pattern also seen after the 1978-1979 Asal-Ghoubbet rift episode (Cattin et al. 2005). The transient deformation patterns are interpreted as one or a combination of continued magma injection into the crust (Pollitz \& Sacks 1996, Cattin et al. 2005) and of stress 


\section{a Rift zone processes}

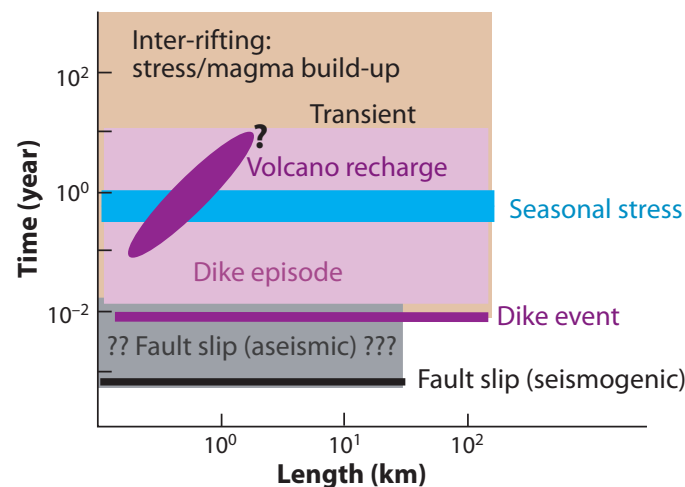

b

Topography formed during dike event
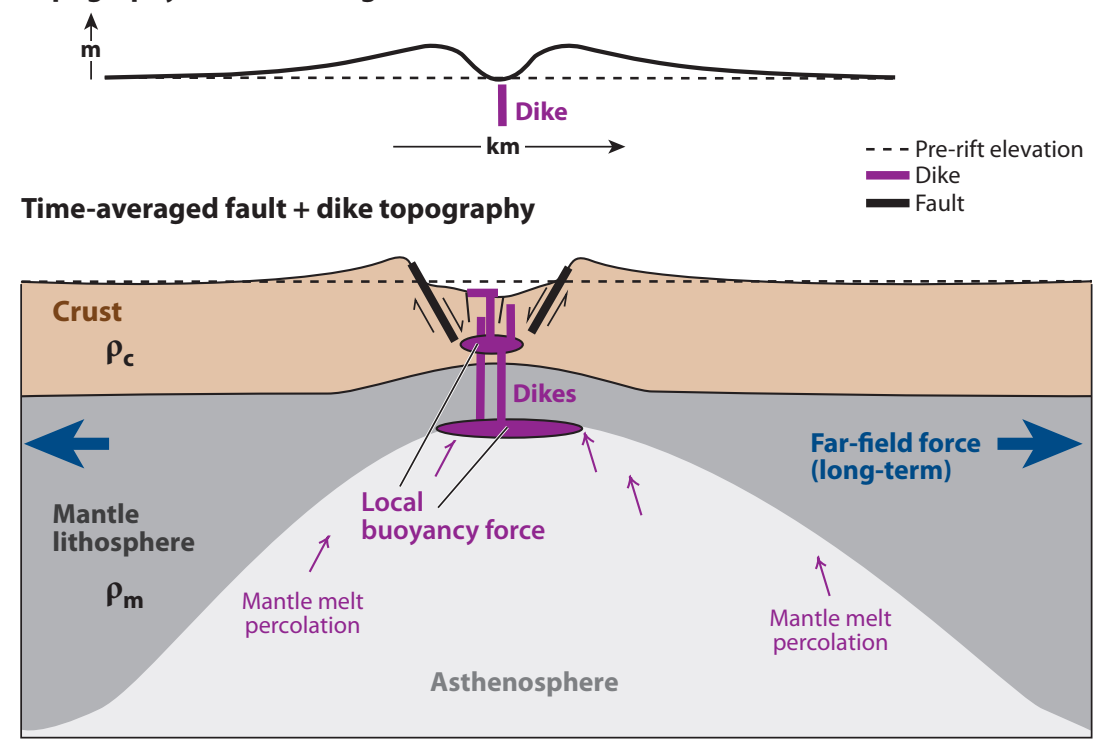

Figure 1

(a) Summary of length and timescales of extensional strain processes. Length and timescales of aseismic deformation poorly constrained at present; magma chamber recharge intervals estimated from 2003-tothe-present studies of Afar volcanoes (Wright et al. 2006, Pagli et al. 2009). (b) Magmatic and faulting processes achieving plate boundary deformation in response to far-field extensional forces and buoyancy forces of lateral density contrasts (magma, topography, crustal thinning, mantle thinning). Vertical crustal movements predicted by dike intrusion alone are shown above the rift valley topography (vertical scale in meters; after Behn et al. 2006). Interstitial mantle melt percolates upward along pressure gradients and then ponds in magma chambers. High chamber pressures and/or tectonic forces may induce rock fracture in the crust; buoyant magma rises into the propagating cracks, yielding a dike-intrusion episode (e.g., Rubin 1995, Delaney et al. 1998). 
relaxation in the viscoelastic mantle after a large-volume intrusion (e.g., Hofton \& Foulger 1996, Nooner et al. 2009) (e.g., Figure 1).

The variability in duration and length scales of dike intrusion, and the missing constraints on brittle deformation during dike intrusion, leads to different conceptual models for fourdimensional strain accommodation at spreading centers. Where magma supply is abundant (fastspreading ridges, mantle hot spots), faults accommodate $5-15 \%$ of extensional strain (Cowie et al. 1993, de Chabalier \& Avouac 1994). Where magma supply is weak or time-varying, faults may accommodate 50\% of extension (e.g., Dauteuil et al. 2001). Tucholke \& Lin (1994) and Thatcher \& Hill (1995) suggested that faults form where or when magma supply for dike intrusion is low, with plate boundary strain accommodated by fault slip. Theory and sparse real-time observations demonstrate that meter-scale normal fault growth and related subsidence also occur during dike intrusion (Brandsdóttir \& Einarsson 1979, Rubin 1995). Is plate boundary deformation largely achieved during intense episodes of dike intrusion and concomitant faulting followed by hiatuses, or are there short cycles of magmatic deformation, followed by repeated fault slip episodes? The current rifting episode in Afar provides fundamental insights to processes maintaining mid-ocean ridge morphology in three dimensions.

An ongoing tectono-magmatic episode of unparalleled scale rocked a sector of the incipient mid-ocean ridge system between Africa and Arabia in 2005. One or more large-volume (1.5$2.5 \mathrm{~km}^{3}$ ) dikes was intruded along a $\sim 65 \mathrm{~km}$-long subaerial segment of the southern Red Sea rift in Afar, and a small-volume silicic eruption occurred at its northern end (Wright et al. 2006, Yirgu et al. 2006, Ayele et al. 2007a, Grandin et al. 2009) (Figures 2 and 3). The rapid geodetic, seismic, and volcanological response initiated by scientists at Addis Ababa University ensured a nearly continuous record of events since the onset of the rifting episode, providing new insights into a rarely observed process (Yirgu et al. 2006, Rowland et al. 2007).

The three-dimensional perspective offered by this subaerial large-volume dike intrusion fundamentally alters our perception of rates and scales of rift zone deformation. The rifting episode occurred in a site of incipient plate rupture where the active rift zone is surrounded by stretched continental crust and mantle. Thus, the Afar events inform and constrain models for the initiation and maintenance of mid-ocean ridge segmentation. This paper synthesizes ongoing seismic, structural, field-calibrated remote sensing, space-based geodetic, and petrologic studies from the southern Red Sea rift zone in Afar, with a focus on the length and timescales of the rifting process from 2005 to 2009. We first review aspects of rifting and dike intrusions critical to our interpretation of the rifting cycle and discuss methods to distinguish dike intrusion (with or without faulting) from faulting alone.

\section{DETECTING RIFT FAULTING AND MAGMA INTRUSION}

Combined seismic, structural, and satellite geodesy studies provide new perspectives on the timescales of rifting processes, and they motivate reconsideration of time-averaged strain patterns. Observations from slow-spreading oceanic rifts show that tensile stresses from far-field plate motions accumulate over decades before being released during relatively short-lived rifting events, followed by decadal-scale transients (e.g., Hofton \& Foulger 1996). A global synthesis of seismicity data from slow-spreading mid-ocean ridges shows that earthquakes account for $10-20 \%$ of plate separation, suggesting that aseismic strain release during dike intrusion accounts for the majority of plate boundary deformation (e.g., Solomon et al. 1988).

Diking events are signaled by an instantaneous and localized extension marked by intense day to week-long swarms of shallow, commonly small to moderate magnitude, and sometimes low-frequency earthquakes that migrate along the length of the rift at rates of $\leq 1 \mathrm{~m} \mathrm{~s}^{-1}$ 


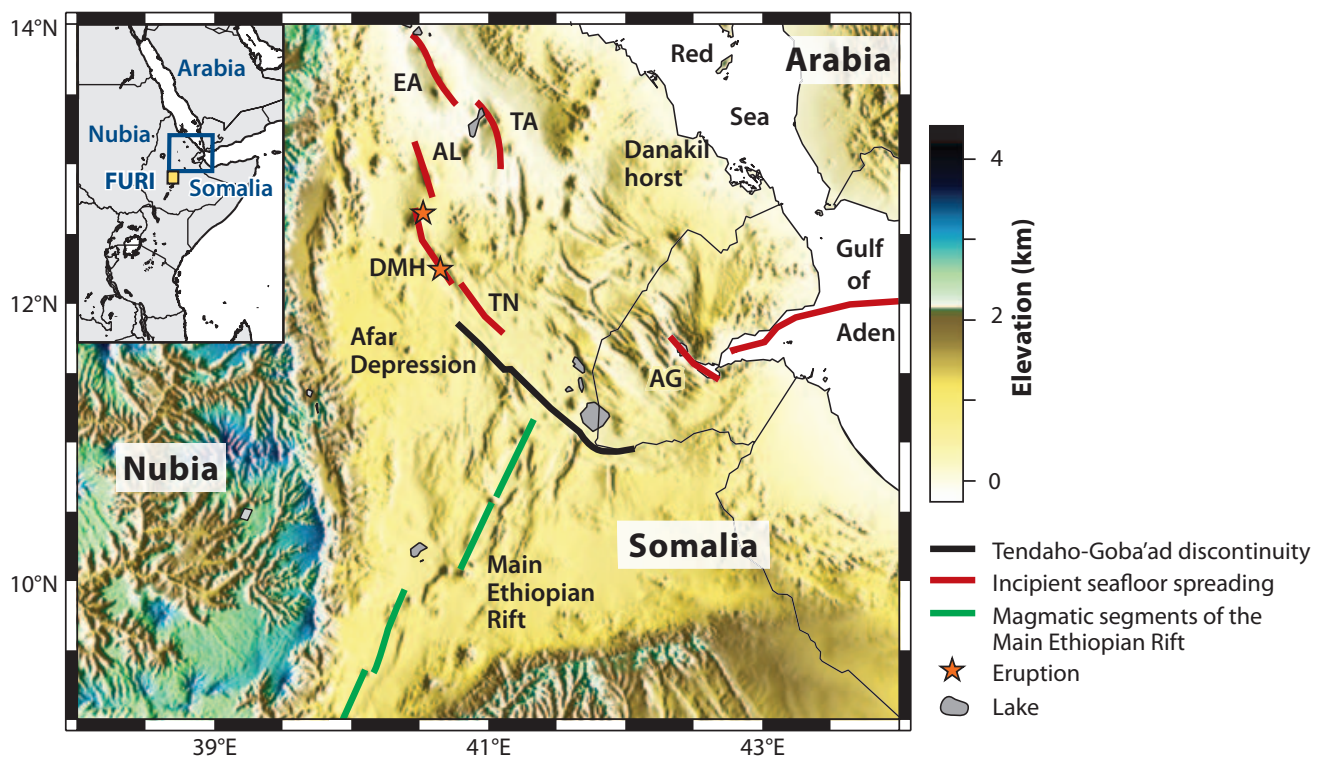

Figure 2

SRTM digital elevation model of the Afar depression and fault-bounded escarpments. Inset shows the location of the study area with respect to northeast Africa and the three diverging plates. The southern Red Sea, western Gulf of Aden, and Main Ethiopian rifts meet in a complex zone near the center of the diagram. Stars are sites of eruptions in 2005 (north) and 2007-2009 (south). Black line marks the oblique-slip Tendaho-Goba'ad discontinuity, the seismically active fault zone separating the Main Ethiopian, Red Sea, and Gulf of Aden rifts. Red lines mark the axial trace of incipient seafloor spreading segments of the southern Red Sea rift and seafloor spreading segments of the Gulf of Aden rift (after Hayward \& Ebinger 1996, Kidane et al. 2003, Grandin et al. 2009). Green lines mark magmatic segments of the Main Ethiopian Rift, which are the current locus of volcanism and extensional strain (e.g., Keir et al. 2006).

Abbreviations: AL, Alayta segment; AG, Asal-Ghoubbet segment; DMH, Dabbahu-Manda Hararo segment; EA, Erta'Ale segment; FURI, GSN seismic station; TA, Tat'Ale segment; TN, Tendaho segment.

(e.g., Einarsson \& Brandsdóttir 1980, Rubin \& Gillard 1998, Dziak et al. 2007). Unlike fault slip events, dike intrusion swarms lack a dominant, larger magnitude earthquake, and they have high event rates for much longer periods than those of comparable magnitude tectonic events (e.g., Tolstoy et al. 2001, Dziak et al. 2007). Theory and observations indicate that migrating seismicity marks inflation-induced tension ahead of a propagating crack, brittle failure above the dike, and/or tension within the wallrock the dike intrudes (e.g., Rubin \& Gillard 1998, Roman \& Cashman 2006). Dike-propagation direction and distance largely depend on the predike level of stress (Buck et al. 2006); solidification time depends on the depth extent of the dike (Fialko \& Rubin 1998, Buck et al. 2006). These propagating dikes are sometimes accompanied by fissural eruptions (e.g., Einarsson \& Brandsdóttir 1980). Dikes are characterized by uplift adjacent to the dike intrusion zone; faulted dikes show subsidence on the hanging-wall side, but the asymmetry is smaller than that predicted by fault slip (e.g., Rubin \& Pollard 1988, Behn et al. 2006). Thus, parallel zones of uplift, comparatively small seismic moment release, and slowly migrating swarms of volcano-tectonic earthquakes characterize dike intrusions.

Satellite geodesy provides a synoptic view of vertical and horizontal crustal movements in rift zones. Interferometric Synthetic Aperture Radar (InSAR) involves differencing the phase from two radar images acquired at different times to map range change between the radar and ground to centimeter precision (e.g., Massonnet \& Feigl 1995). Where both ascending and descending orbits span comparable time periods, the horizontal and vertical components of surface deformation can
InSAR:

Interferometric Synthetic Aperture Radar 


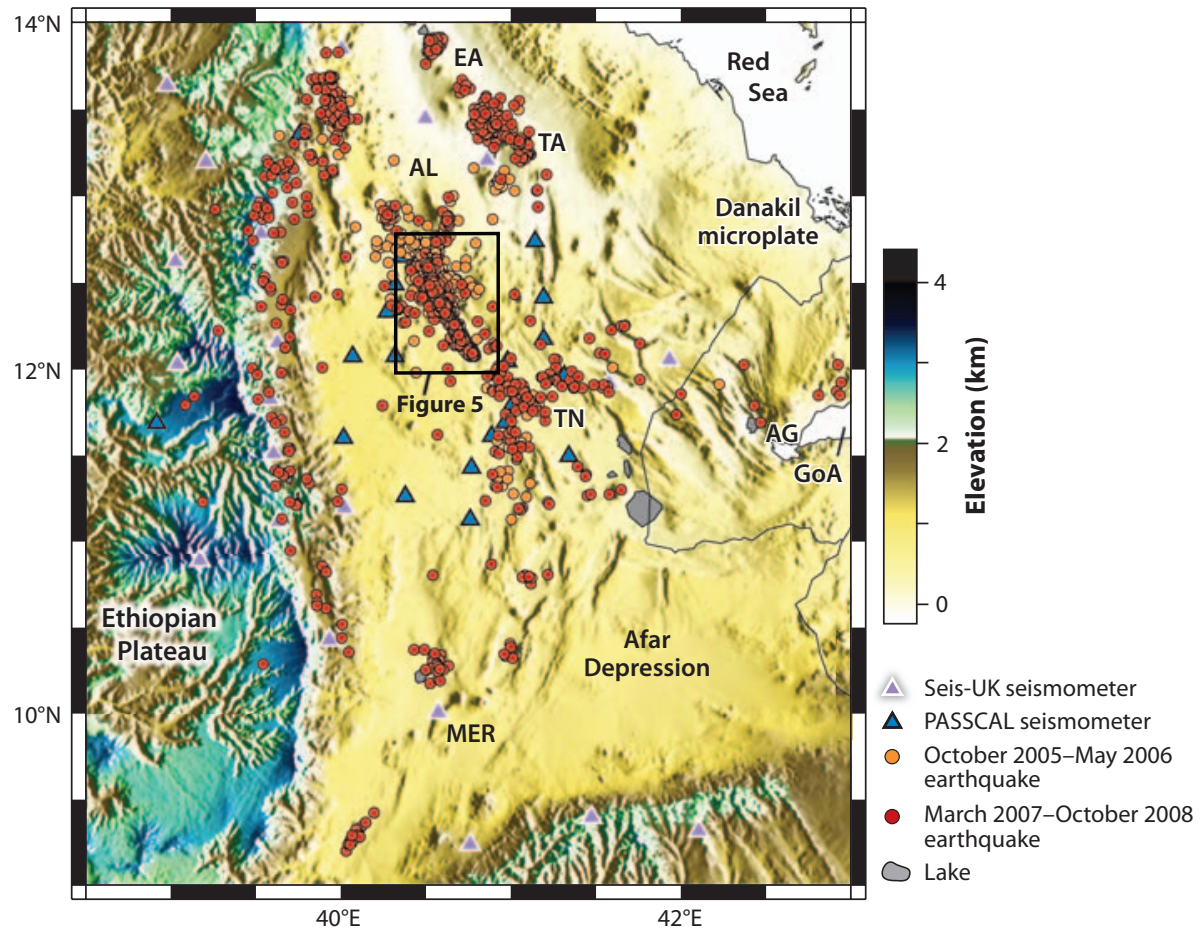

Figure 3

Regional compilation of seismicity recorded on four or more Seis-UK and PASSCAL seismometers from October 19, 2005, to November 2009 (Belachew et al. 2009, Hammond et al. 2009). Most of the events are $\mathrm{M}_{\mathrm{L}}>$ 2.5; see Ebinger et al. (2008) and Keir et al. (2009) for details. Box encloses Dabbahu-Manda Hararo segment, shown in more detail in Figure 5. Incipient seafloor spreading segments marked by faulted shield volcanoes with or without silicic eruptive centers: AG, Asal-Ghoubbet segment; EA, Erta'Ale segment; TA, Tat'Ale segment; AL, Alayta segment; TN, Tendaho segment. One band of seismicity follows the faulted graben system along the western escarpment; discontinuous strands connect the Erta'Ale, Tat'Ale-AlaytaDMH, and Tendaho segments to the Main Ethiopian Rift (MER). The connection to the Gulf of Aden (GoA) is less clear and will improve through collaborative studies with colleagues in Djibouti.

GPS: Global Positioning System

be resolved (e.g., Wright et al. 2004). The temporal resolution of InSAR is restricted by monthlong satellite orbits and acquisition constraints. Continuous Global Positioning System (GPS) observations provide detailed information on the vertical and horizontal components of crustal deformation as well as the time-varying rates of plate motions. Seismic and geodetic techniques allow us to map vertical and horizontal crustal movements in three dimensions and to quantify aseismic strain, enabling discrimination between fault slip and dike intrusion during tectonomagmatic episodes, as well as the transient response of the plate to the stresses induced by the dike intrusion.

Dike opening and fault slip area can be estimated through comparisons between surface deformation and simulations of surface deformation predicted by elastic and visco-elastic dislocation models (e.g., Okada 1985, Hamling et al. 2009). Deflating or inflating magma bodies can be represented as equivalent pressure sources (Mogi 1958) and be included in the data inversions to retrieve magma volume (e.g., Wright et al. 2006, Grandin et al. 2009). Although these models are nonunique, they can be constrained by and tested against independent seismic, structural, 
magneto-telluric, and petrological constraints on the geometry, distribution, and composition of magma sources, the length and height of dikes, and the distribution of fault slip.

\section{TECTONIC SETTING}

Incipient seafloor spreading centers in the Afar rift are surrounded by continental crust and mantle lithosphere stretched and intruded during the past $30 \mathrm{Ma}$ as Africa and Arabia have rifted apart (McKenzie et al. 1970) (Figure 2). Although the faulting and magma intrusion processes occurring in Afar are representative of mid-ocean ridges, the trailing continental plates on either side of the rift and anomalously hot mantle lead to differences in magma sources, compositions, and production rates from those on mid-ocean ridges, as outlined below.

The Red Sea, Gulf of Aden, and East African rift arms formed within a Paleogene flood basalt province associated with a mantle plume (e.g., Courtillot et al. 1980; Ebinger \& Sleep 1998; Beccaluva et al. 2009; Bastow et al. 2008, 2010). The thermal anomaly associated with the mantle upwelling persists today, as shown by low $\mathrm{P}$ - and S-wave upper mantle velocities beneath the uplifted plateaux of Arabia and northeast Africa (e.g., Debayle et al. 2001, Benoit et al. 2006, Montelli et al. 2004, Bastow et al. 2008). The magnitude of both shear-wave velocity anomalies and seismic velocity anisotropy can be modeled with upper mantle containing a melt fraction of $<1 \%$ (e.g., Kendall et al. 2006) to as high as 4\% (Keranen et al. 2009).

The Afar depression is bounded by the northwest-southeast trending Danakil horst, generally considered a rigid block rotating counterclockwise as the Afar rift opens (e.g., Souriot and Brun 1992, Eagles et al. 2002). The Tendaho-Goba'ad Discontinuity is a fault scarp separating the zone of subeast-to-west extension in the East African rift from the northeast-southwest opening Red Sea rift (Figure 2). Geodetic data indicate an average spreading rate of $\sim 15 \mathrm{~mm}_{\text {year }}{ }^{-1}$ across the Nubia-Arabia plate boundary, rates comparable to those in Iceland (Vigny et al. 2006).

Rifting along the southern Red Sea within the Afar depression commenced by 29 Mya, roughly coincident with the 31-29 Mya flood basalt sequences (e.g., Wolfenden et al. 2005). Rifting has progressed to seafloor spreading along the length of the Gulf of Aden and in sectors of the Red Sea north of $14^{\circ} \mathrm{N}$ (e.g., Abdallah et al. 1979, Bonatti 1985, Manighetti et al. 1997) (Figure 2). The crust beneath the Ethiopian and Yemen plateaux is $35-45 \mathrm{~km}$ in thickness, with up to $10 \mathrm{~km}$ of magmatic underplating along the southern Red Sea margin and central Ethiopian plateau (e.g., Maguire et al. 2006, Stuart et al. 2006, Dugda and Nyblade 2006). Assuming that the crust beneath the Afar was also underplated, the $\sim 23-\mathrm{km}$-thick crust beneath the broad Afar depression indicates a 50\% reduction in thickness. Refraction/wide angle reflection studies show a velocity structure similar to the crust beneath Iceland (e.g., Berckhemer et al. 1975, Makris \& Ginzburg 1987, Maguire et al. 2006). Both refraction and receiver function studies reveal localized crustal thinning beneath the narrow, seismically and magmatically active rift zones; crustal thickness is 13-16 km compared with 20-26 km beneath Afar (Dugda and Nyblade 2006, Dugda et al. 2007, Stuart et al. 2006, Hammond et al. 2009).

Since $\sim 3$ Mya, faulting and volcanism within the Afar depression have localized to $\sim 60-\mathrm{km}-$ long, 10-km-wide zones of fissural flows, basaltic cones, stratovolcanoes, shallow seismicity, and positive gravity anomalies (Figures 2 and 3) (Barberi \& Varet 1977; Hayward \& Ebinger 1996; Manighetti et al. 1997; Doubre et al. 2007a, 2007b). These magmatic segments in the southern Red Sea and Aden rift initiated, and probably propagated, after a pulse of volcanic activity at approximately 2 Mya, but some segments remain undated (Lahitte et al. 2003, Kidane et al. 2003). The magmatic segments are similar in size, morphology, structure, and spacing to slow-spreading mid-oceanic ridge segments (Hayward \& Ebinger 1996, Oppenheimer \& Francis 1998). They are the locus of magma intrusion and become the sites for the formation of new igneous crust 
DVC: DabbahuGab'ho volcanic complex

AVC: Ado'Ale volcanic complex by dike intrusions, as in the Asal rift at the propagating tip of the Gulf of Aden rift (Cattin et al. 2005; Doubre et al. 2007a, 2007b). Unlike slow-spreading mid-ocean ridges, incipient seafloor spreading segments in Afar lack oblique or orthogonal fault systems marking transforms.

Earthquakes recorded on a combined Seis-UK and PASSCAL network show a belt of seismicity along the grabens bounding the western escarpment, and multiple strands of epicenters north and west of the Asal-Ghoubbet rift, as well as the Main Ethiopian Rift (Figure 3). The spatial distribution of seismicity is representative of longer-term patterns from catalogs of earthquakes recorded on global and regional networks (Gouin 1979, Kebede \& Kulhánek 1994, Ayele \& Kulhánek 1997, Jacques et al. 1999, Hofstetter \& Beyth 2003, Ayele et al. 2007b). Temporary arrays around the regional capital, Semara (Gresta et al. 1997), the Erta'Ale lava lake (Jones et al. 2006), and a sparse permanent network in Eritrea (Ogubazghi et al. 2004; Hagos et al. 2006a, 2006b) showed frequent, small magnitude events, but much of the rest of the region was unmonitored.

The 2005 Dabbahu rifting episode occurred in the southernmost Red Sea rift near the Afar triple junction (Figures 2 and 3). The first event ruptured the length of a previously mapped magmatic segment within the Manda-Hararo rift zone, referred to as the Dabbahu-Manda Hararo segment (Barberi \& Varet 1977, Hayward \& Ebinger 1996, Lahitte et al. 2003, Grandin et al. 2009) (Figures 2 and 3).

\section{AFAR RIFTING CYCLE}

Below, we outline the time sequence of dike intrusion, faulting, and surface deformation as deduced from seismicity, field mapping, and geodetic studies, making reference to the timeline of discrete dike intrusions and fissural eruptions (Figure 4). The initial and largest magma intrusion sequence occurred in a geographically remote area of the Afar depression, and no seismic or geodetic monitoring arrays were in place prior to the onset of activity. Hence, interpretations of key aspects of the large-volume magma intrusion in 2005 have been elucidated from subsequent dike intrusions and fissural eruptions. Work in progress promises to reveal the full three-dimensional magmatic system, from mantle source to surface, and magmatic segment linkage (e.g., Hammond et al. 2009, Guidarelli et al. 2009, Kidane et al. 2003, Pagli et al. 2009, Ferguson et al. 2010).

Figure 5 illustrates the densely faulted Dabbahu-Manda Hararo rift segment marked by silicic centers in the Dabbahu-Gab'ho volcanic complex (DVC) in the north and the Ado'Ale volcanic complex (AVC) near the segment center; the southern termination is marked by an eastward stepover of eruptive centers and faults around $12^{\circ} \mathrm{N}$ (Rowland et al. 2007). Prior to the onset of voluminous dike emplacement, intermittent seismicity started beneath the DVC in April 2005 (Ayele et al. 2009). Sparse InSAR imagery reveals inflation of the Gab'ho volcano between April 2004 and May 2005 (Wright et al. 2006).

\section{Figure 4}

Depth-averaged dike opening for the top $10 \mathrm{~km}$ of the crust beneath the Dabbahu-Manda Hararo segment plotted against distance along the segment from north to south. Zero is north flank of Dabbahu volcano. Lines represent the average opening for each of the dike intrusions (labeled). Solid graph (bottom) shows the cumulative opening for all the dikes in the same colors as each of the individual graphs, in addition to the September 2005 intrusion (orange) (based on Hamling et al. 2009). Wright et al. (2006) outline the timeline of deformation within the Dabbahu-Gab'ho volcanic complex (DVC). See Grandin et al. (2009) for comparisons of slip along westward- and eastward-dipping faults and strains, which are larger near the mid-segment for the September 2005 dike. 


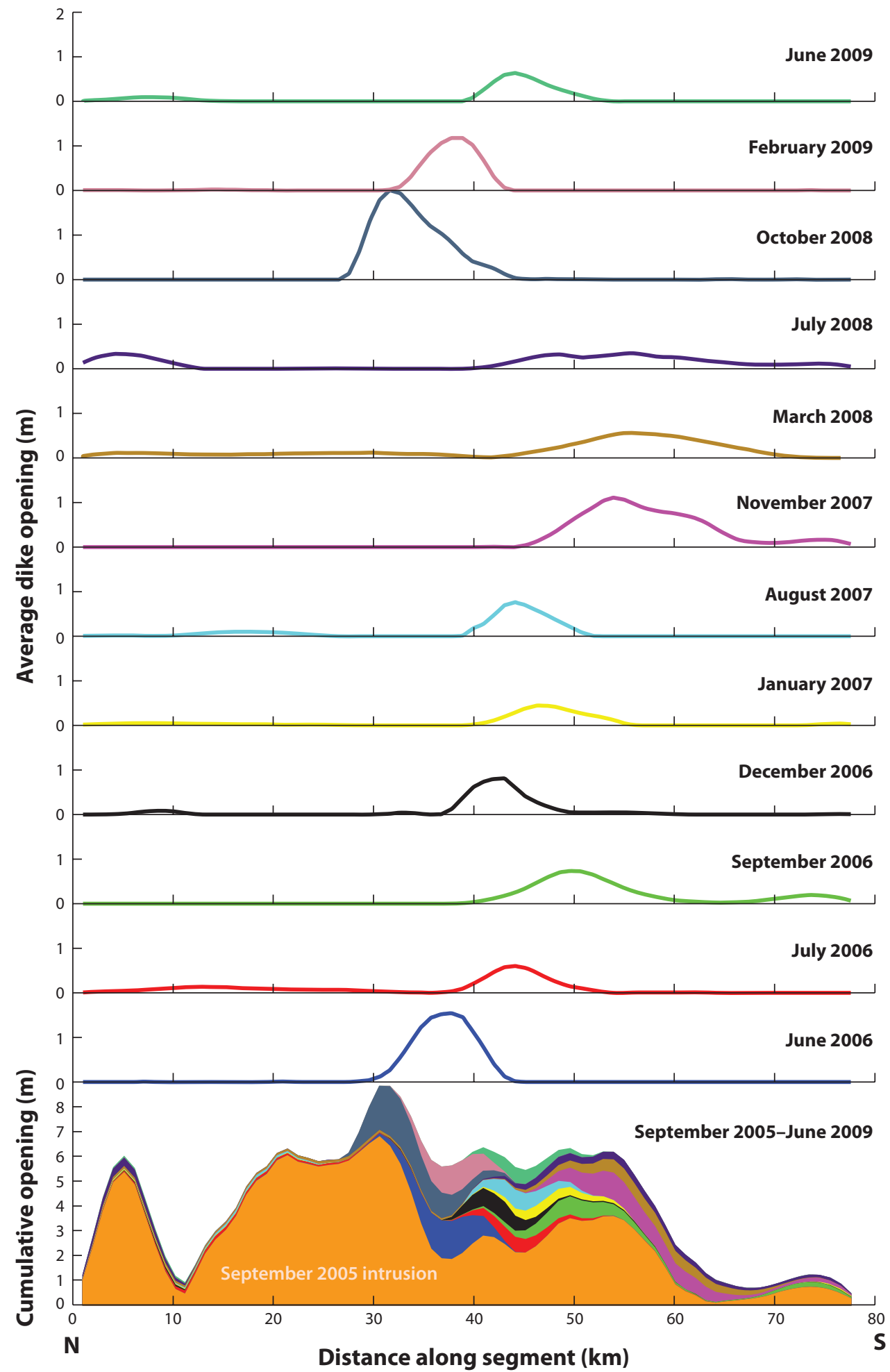




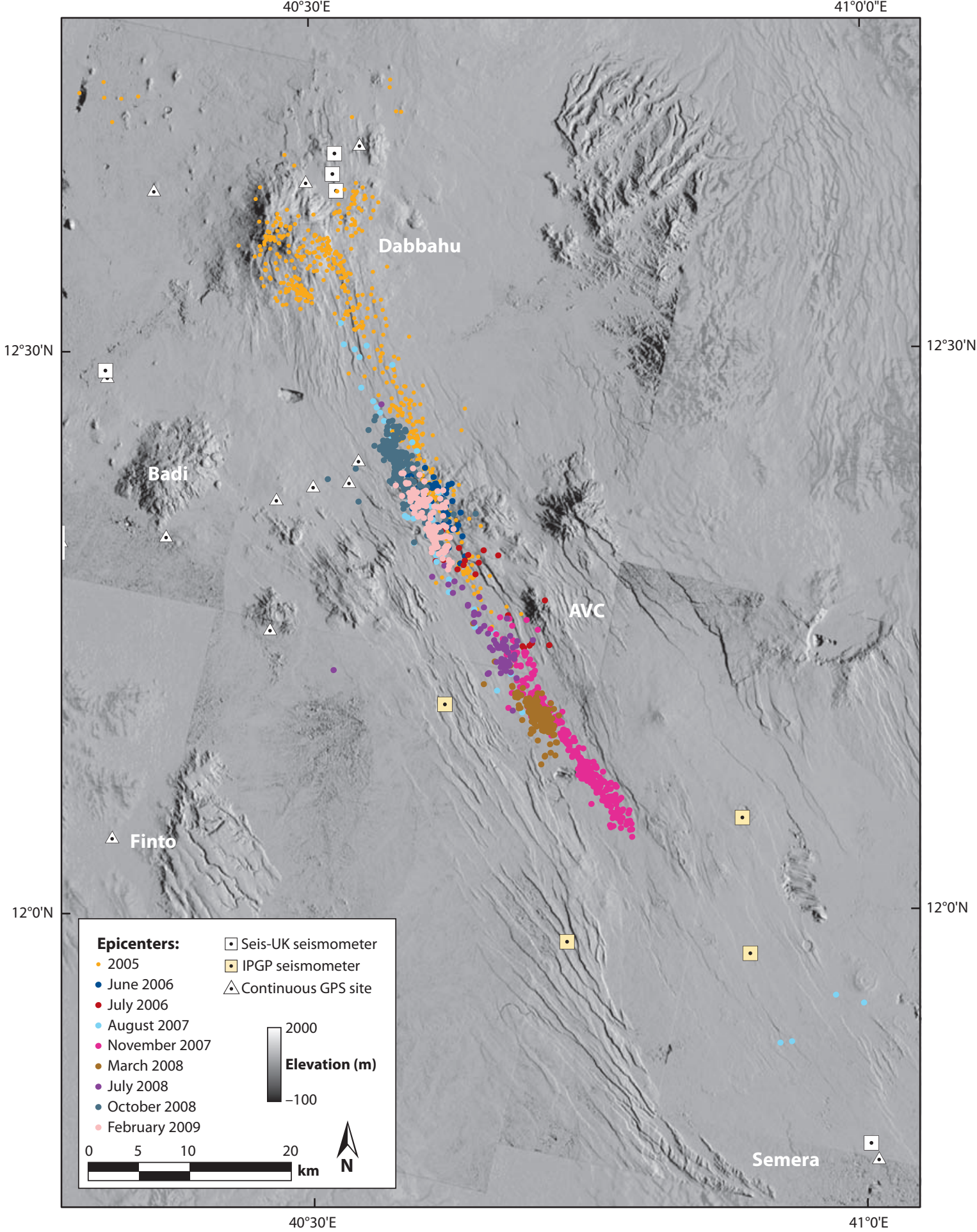




\section{Dike Event 1: September 2005, Rift Cycle Onset}

Ayele et al. (2009) used field observations, eyewitness accounts, and regional seismic records to derive a spatiotemporal pattern of dike intrusion and faulting from September to October 2005. These analyses provide additional detail to the surface deformation deduced from geodetic data (Wright et al. 2006, Ayele et al. 2007a, Barisin et al. 2009, Grandin et al. 2009) and fault mapping (Rowland et al. 2007).

The first indication of increased tectonic activity was a $M_{w} 4.5$ earthquake on September 4. On September 14, a Mw 5.0 earthquake occurred beneath the DVC (Figures 5 and 6). Activity subsided but then restarted on September 20 and continued until October 4. Initial reports from the region were confusing, and scientists initially deployed to Erta'Ale lava lake on another rift segment, $150 \mathrm{~km}$ to the north (Yirgu et al. 2006). Ayele et al. (2009) worked with seismologists in neighboring countries to relocate 420 earthquakes; 210 were $\mathrm{Mw} \geq 3$.6. This two-week period of continuous seismic activity peaked between September 24 and 26, with sporadic tremors and signals of ultralong period ( $\sim 500 \mathrm{~s})$ recorded at station FURI $450 \mathrm{~km}$ southwest of the rift zone (Ayele et al. 2009) (Figure 2, inset). On September 26, a 500-m-long, 60-m-deep, north-southoriented vent opened $7 \mathrm{~km}$ northeast of Dabbahu volcano (Yirgu et al. 2006) (Figures 2 and 5). The time-distance relations of the earthquake swarms show two centers: the DVC in the north and the AVC near the center of the segment (Ayele et al. 2009) (Figure 5). Earthquake swarms initiate beneath the AVC and migrate northward with an average rate of $15-30 \mathrm{~cm} \mathrm{~s}^{-1}$ (Ayele et al. 2009).

The 120-km-by-25-km zone of moderate-sized earthquakes and the volcanic eruption pointed to a segment-wide magma intrusion event. The pattern of surface displacement deduced from satellite radar data confirmed meters of surface deformation along the $65-\mathrm{km}$-long length of the Dabbahu-Manda Hararo segment (Wright et al. 2006, Ayele et al. 2007a, Barisin et al. 2009, Grandin et al. 2009) (Figure 6). The pattern of vertical crustal movements matched faulted dike intrusion models: parallel zones of uplift flanking a faulted graben above the dike intrusion (Figures $\mathbf{6}$ and $\mathbf{1} b$ ). The combination of synthetic aperture radar and subpixel correlations of radar and SPOT images enabled Barisin et al. (2009) and Grandin et al. (2009) to distinguish horizontal from vertical surface displacements, providing additional details of the co-dike intrusion faulting. Graben width increases from $2 \mathrm{~km}$ in the north to $4 \mathrm{~km}$ in the south, with preferential slip along westward-dipping faults (Grandin et al. 2009). Roughly circular zones of subsidence at Dabbahu and Gab'ho volcanoes indicate pressure release and/or volume changes in the magma chambers beneath these volcanoes (Wright et al. 2006).

Aerial photography along the segment and field observations at the northern and central parts of the segment confirm that substantial fault growth accompanied dike intrusion (Rowland et al. 2007). Vertical offsets of 2 to $3 \mathrm{~m}$, and horizontal offsets of $<3 \mathrm{~m}$, accrued on faults and associated fissures within a $5-\mathrm{km}$ swath that extended along the strike over most of the $65-\mathrm{km}$ length of the segment (Figures 6-8). The locus of brittle strain lies $5 \mathrm{~km}$ to the east of the rift axis in the northern half of the segment, demonstrating that dike intrusion is not constrained to the

\section{Figure 5}

Epicenters of earthquakes in the Dabbahu-Manda Hararo segment from October 19, 2005 to present, with a 6-month gap between October 2006 and March 2007, color-coded according to Figure 4. For details on 2005-2006 data and June-July 2006 dikes, see Ebinger et al. 2008 and Keir et al. 2009, respectively. Squares are Seis-UK seismic stations operational in 2005/2006 and IPGP seismometers deployed in 2007; triangles are continuous GPS sites (see details in Nooner et al. 2009). The composite digital elevation model is constructed from Spot 5 imagery; vertical resolution $<10 \mathrm{~m}$. Ado'Ale volcanic complex (AVC) is a chain of rifted silicic centers at the segment center. Semera is the Afar region's capital. 


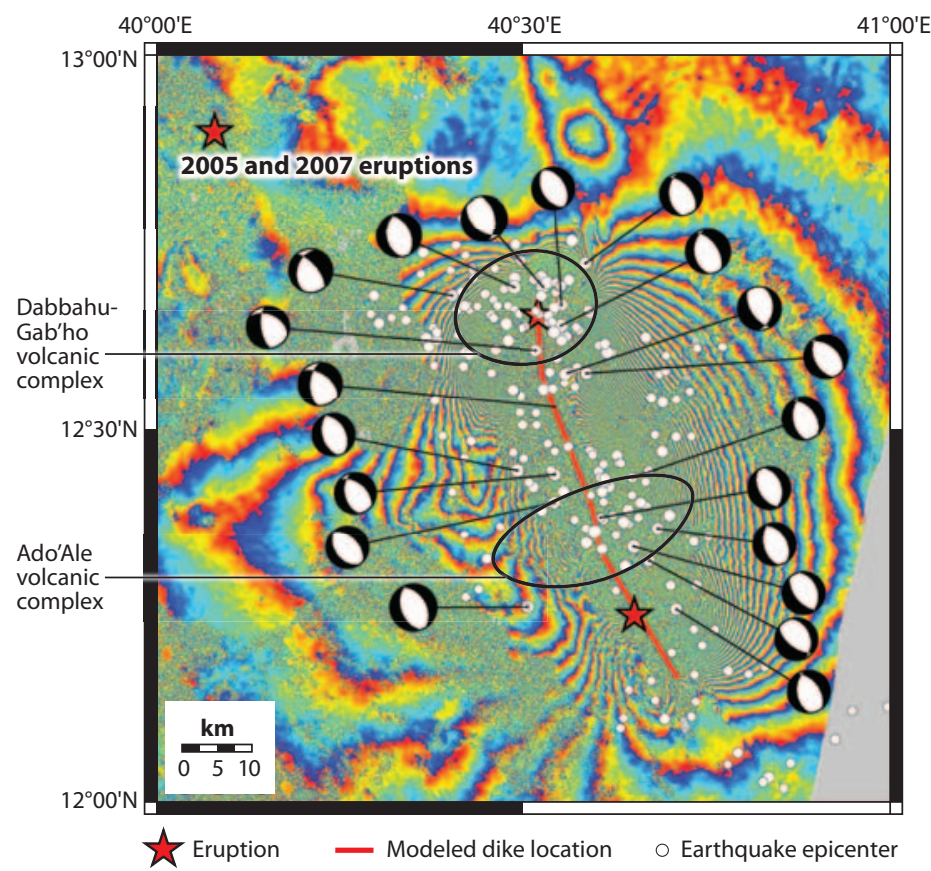

Figure 6

Fault plane solutions (lower hemisphere projections) of earthquakes that occurred during the onset of the rifting cycle in the Dabbahu-Manda Hararo segment during the period September 4-October 4, 2005. Solutions are superposed on the descending track 49 interferogram formed by differencing satellite radar images acquired on May 6 and October 28, 2005. Each repeated color cycle, or fringe, corresponds to 2.6-cm deformation (based on Ayele et al. 2009). Red stars indicate sites of the 2005 silicic eruption (north) and the 2007-2009 fissural basalt eruptions (south-center).

geomorphic axis of the rift (Rowland et al. 2007) (Figure 7). The along-axis variations in faulting and geodetic strain suggest three or more dikes were intruded (Grandin et al. 2009).

Elastic dislocation models of the surface deformation require assumptions regarding the shape and physical location of the dike, leading to differences in estimated dike opening, magma chamber deflation, and border fault slip. Ayele et al. (2007) and Wright et al. (2006) focused on the large-scale deformation and magma source zones, whereas Barisin et al. (2009) and Grandin et al. (2009) focused on the strain partitioning between faults and magma intrusion. Horizontal opening varies from 3 to $10 \mathrm{~m}$ along the length of the rift (Wright et al. 2006, Grandin et al. 2009). The major differences in the models lie in the analyses of the asymmetric uplift of the rift flanks and the

Figure 7

Central Dabbahu magmatic segment. (a) Corona image, acquired in 1965, showing the central Dabbahu magmatic segment in the vicinity of the dissected Ado'Ale volcanic complex (from Rowland et al. 2007). Horizontal resolution is $\sim 5 \mathrm{~m} \mathrm{pixel}^{-1}$. Arrows indicate structures that are overprinted by more recent rifting episodes. The arrow marked $c$ shows the viewing direction for the photograph in panel $c$. (b) Structural interpretation of stereo-Corona images (from Rowland et al. 2007) showing the main tectonomagmatic features in this region. $(c)$ View south showing structural overprinting of en echelon arrays of vertical normal faults and extension fissures, which cut young basalt lava flows on the western flank of the rift (viewing direction shown by arrow in panel $a$ ). Dissected silicic domes on the eastern flank of the Ado'Ale volcanic complex are visible in the far left distance. 

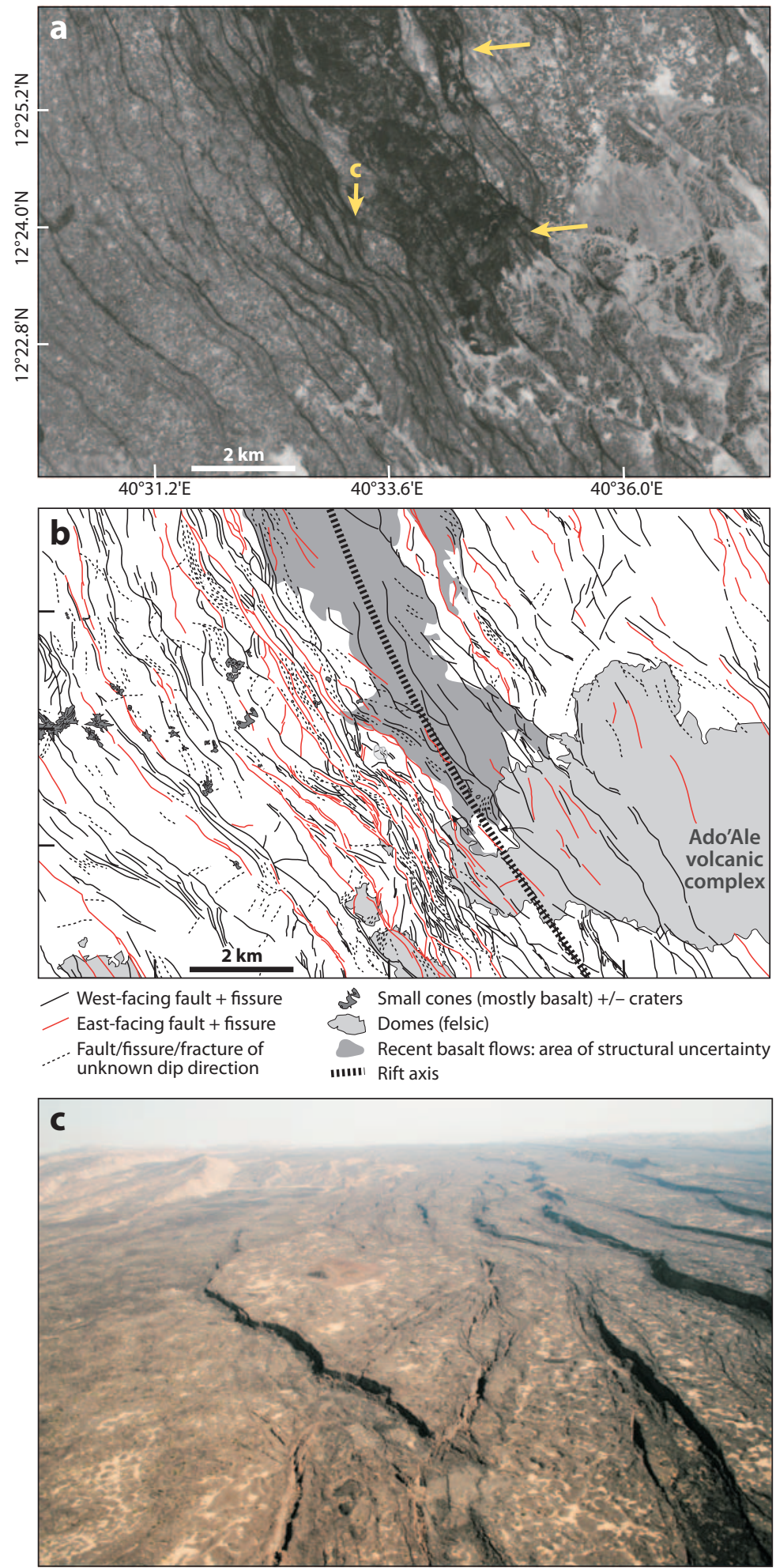

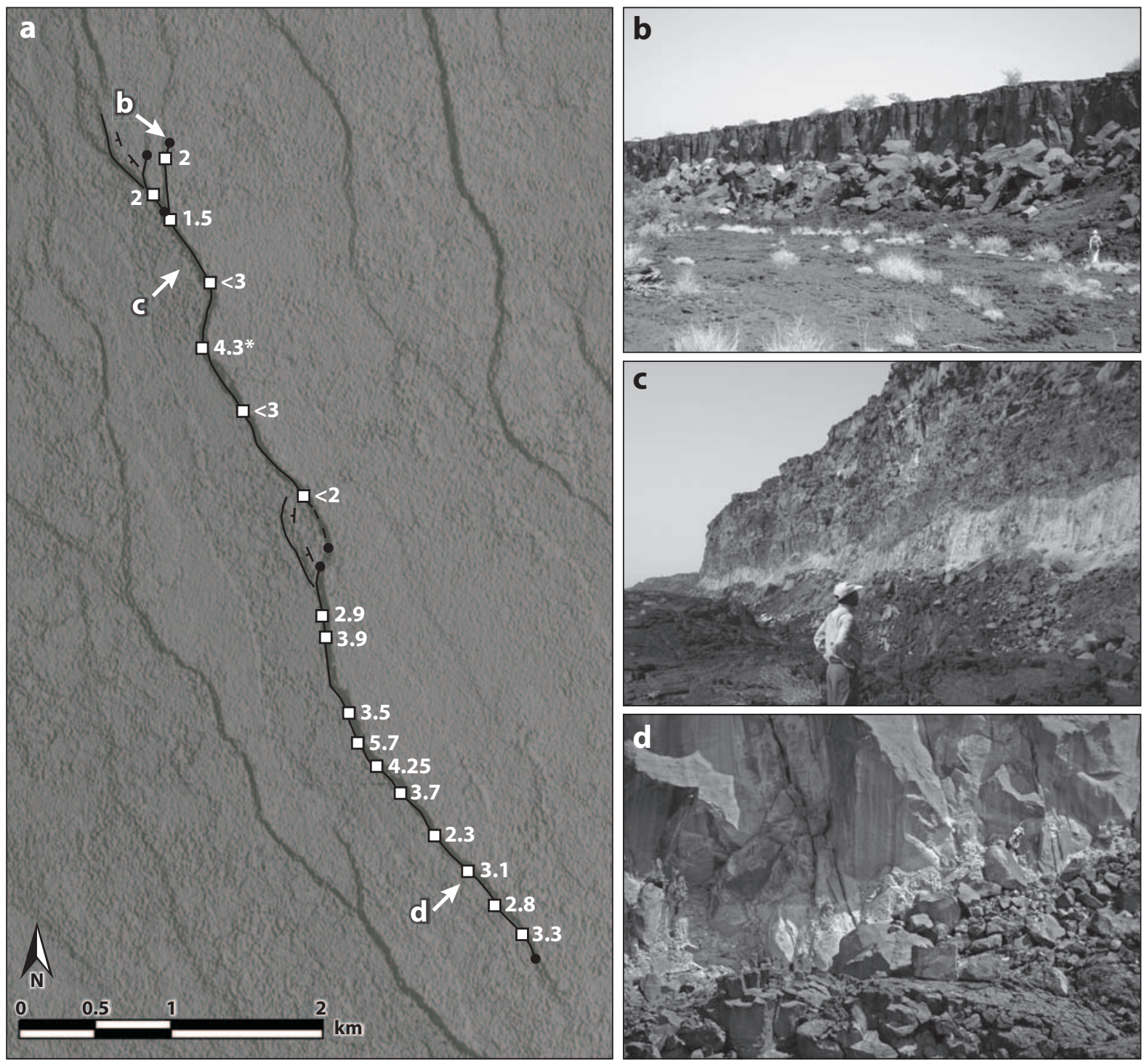

\section{Figure 8}

Incremental slip associated with the 2005 intrusive event. (a) Digital elevation model of the eastern flank of the Dabbahu Rift north of the Ado'Ale volcanic complex annotated with measurements of dip slip on two soft-linked fault segments with scarp heights $>30 \mathrm{~m}$. The asterisked slip measurements likely include a component of monocline collapse in the hanging wall. Locations of photographs $b-d$ are labeled with arrows. (b) New slip diminishes to zero behind a 100-m-long section of collapsed footwall. (c) Fresh slip visible as a light-colored band at the base of the scarp. This $>1000$-m-long section of the fault maintains a near constant slip increment of between 2 and $3 \mathrm{~m} .(d)$ Fresh slip band at the southeast tip of fault segment.

larger fault slips on west-facing faults. Barisin et al. (2009) reproduced the observations with an $80 \mathrm{~W}$-dipping dike, whereas Grandin et al. (2009) obtained good fits with asymmetric slip conditions on the western and eastern side of the rift.

Models of subsidence patterns in the InSAR data indicate that no more than $25 \%$ of the magma originated from shallow magma chambers beneath the Dabbahu composite volcano and the much 
smaller Gab'ho rhyolitic center at the northern tip of the rift segment (Wright et al. 2006, Ayele et al. 2007a, Grandin et al. 2009). Gas exsolution during magma withdrawal and/or a deeper magma chamber would increase estimates of magma extracted (e.g., Rivalta \& Segall 2008). The magnitude of deformation across the narrow rift zone, as well as existing topography, complicated attempts to separate a long wavelength signal of subsidence associated with deeper sources, but source zones for subsequent dikes were also difficult to elucidate, as outlined in subsequent sections.

Field observations and the pattern of seismicity are largely consistent with the strain distribution induced by dike intrusion to within 2.5 - $\mathrm{km}$ subsurface and by fault slip above the dike; slip occurred along the entire rift segment (Wright et al. 2006, Rowland et al. 2007, Grandin et al. 2009) (Figures 6-8). The combined geodetic moment release is an order of magnitude more than the seismic moment release, indicating that nearly all the strain during the rifting episode was accommodated aseismically by the intrusion of multiple dikes (Wright et al. 2006, Grandin et al. 2009, Ayele et al. 2009). We discuss strain partitioning between faulting and magmatism and magma source zones below after first presenting clues from the ongoing rift process.

\section{Interdike Period: October 2005-June 2006}

The 9-month period between the initial, segment-long dike intrusion and the next major dike intrusion event provides additional information on the geometry of the initial dike intrusion as well as the pressurized magma chambers. Migrating swarms of earthquakes recorded on a temporary seismic network suggest that some dike intrusions continued until at least November 4, 2006 (Ebinger et al. 2008) (Figure 5). Along the length of the segment, earthquake hypocenters lie between $10 \mathrm{~km}$ and the surface, and they show rift-normal opening. The postdiking earthquakes mimic the geodetically determined distribution of the 2005 dike, with the most intense zones of seismicity corresponding to patches of greater strain release at depth (Figure 5). Thermal stresses for a large-volume intrusion are on the order of tens of mega Pascal for months after a large-volume intrusion, and predicted yield stress envelopes at the dike wall fit the observed depth extent of earthquakes, suggesting that much of the postdike seismicity occurs in response to the large temperature contrast across the dike walls. Earthquakes not only illuminate the rock breaking in front of and above the dike during intrusion, but they also may mark the dike's geometry after intrusion (Coté et al. 2009). With these assumptions, the dike was $8-10 \mathrm{~km}$ in height (Ebinger et al. 2008).

Persistent seismic swarms at two sites on Dabbahu volcano coincide with areas of deformation identified in the InSAR data, suggesting changes in magma volume pressurization and/or magma movement at two levels: 8-10 km and $\sim 2 \mathrm{~km}$ (Ebinger et al. 2008) (Figure 6). Feldspar-hosted melt inclusions in products of the most recent eruptions suggest crystallization occurs from depths of $\sim 12 \mathrm{~km}$ (A. Philpotts, personal communication). However, fluid-inclusion studies of Dabbahu lavas suggest magma is temporarily stored at depths between 3.5 and $6 \mathrm{~km}$ prior to eruption (Field et al. 2008). A $\sim 2-\mathrm{km}$-diameter chamber at 4-km subsurface may underlie the 2005 eruptive vent. Gab'ho was aseismic, but it uplifted rapidly during this interdike period.

\section{Dike Events 2-3: June 2006, July 2006}

Keir et al. (2009) analyzed seismicity induced by intrusion of a $\sim 8$-km-long, $\sim 2$-m-wide dike on June 17, 2006 and a $\sim 10$-km-long, $\sim 1$-m-wide dike on July 25, 2006. Three seismic stations were available to locate the earthquakes, only loosely constraining depths. Models of ground deformation determined using InSAR suggest these dikes intruded the upper $\sim 10 \mathrm{~km}$ (Table 1). Both earthquake clusters are characterized by $\sim 4-5$ h-long migration of seismicity 
Table 1 Distributed opening model parameters for each of the dikes*

\begin{tabular}{|c|c|c|c|c|}
\hline Date & Moment $10^{18} \mathrm{Nm}$ & Volume $\left(\mathrm{km}^{3}\right)$ & Maximum opening (m) & Depth $(\mathrm{km})$ \\
\hline June 2006 & 5.44 & $0.12 \pm 0.01$ & $2.2 \pm 0.2$ & $0-10$ \\
\hline July 2006 & 3.25 & $0.042 \pm 0.017$ & $1.1 \pm 0.1$ & $0-6$ \\
\hline December 2006 & 3.05 & $0.058 \pm 0.011$ & $1.78 \pm 0.1$ & $1-6$ \\
\hline January 2007 & 2.07 & $0.037 \pm 0.013$ & $0.7 \pm 0.1$ & $2-7$ \\
\hline March 2008 & 3.72 & $0.088 \pm 0.02$ & $0.9 \pm 0.1$ & $4-10$ \\
\hline July 2008 & 3.21 & $0.066 \pm 0.02$ & $1.3 \pm 0.2$ & $0-5$ \\
\hline October 2008 & 7.88 & $0.17 \pm 0.001$ & $3.1 \pm 0.16$ & $1-9$ \\
\hline February 2009 & 3.02 & $0.077 \pm 0.005$ & $1.5 \pm 0.1$ & $0-9$ \\
\hline
\end{tabular}

*The depth range is delimited by the condition that dike opening is $1 \mathrm{e}^{-1}$ of the maximum (Hamling et al. 2009).

along the dike length, and migration of seismicity is temporally coincident with timing of dike opening constrained using local continuous GPS data (Figures 4 and 9). Seismic moment release accounts for only $5 \%$ of $3.71 \times 10^{18} \mathrm{Nm}$ geodetic moment released on June 17 and $<1 \%$ of $2.2 \times 10^{18} \mathrm{Nm}$ released on July 25. Magma intrusion, therefore, accounts for the vast majority of deformation during diking. Neither intrusion is accompanied by subsidence of the AVC, suggesting a relatively deep magma chamber $(\geq 10 \mathrm{~km})$, expansion of magma in the chamber caused by gases exsolving as pressure drops during magma escape, and/or large stiffness of a spherical magma chamber (Keir et al. 2009).

\section{Dike Events 4-6: September 2006, December 2006, January 2007}

On September 10, 2006, a swarm of $14 \mathrm{M}_{\mathrm{L}}$ 2.6-3.4 earthquakes was detected near the AVC. Interferograms indicate a fourth dike intrusion (Figure 4, Table 1). The total seismic moment was $0.1 \%$ of the total geodetic moment (Hamling et al. 2009). There was a gap in seismic monitoring between October 2006 and March 2007 when the Seis-UK network was removed and a PASSCAL array was installed. The timing and spatial extent of seismic strain for the December and January dikes, therefore, was constrained solely by GPS and InSAR (Table 1). The model for Dike Event 5 (December) suggests a 7-8 km-long dike intruded the central rift sector. Normal faults slipped by no more than $0.9 \mathrm{~m}$ (Hamling et al. 2009). A small-volume dike was intruded on January 14, 2007, along the same area as the September 2007 dike (Figure 4, Table 1).

\section{Dike Event 7: August 2007 Karbahi Fissural Eruption}

The seismic swarm started at 23:29 on August 11 with an earthquake near the center of the rift segment (Belachew et al. 2009). Local pastoralists confirmed that the first sign of activity was a sudden, southward-propagating cracking noise on Sunday, August 12. Only minor ground tremor was felt near the site but not on seismometers located $\sim 25 \mathrm{~km}$ west and south. Small magnitude $\left(\leq M_{L} 3\right)$ earthquakes ceased at about 02:00 on August 13, prior to the onset of fire fountaining at approximately 14:30 (Belachew et al. 2009). This activity continued with variable intensity until it 


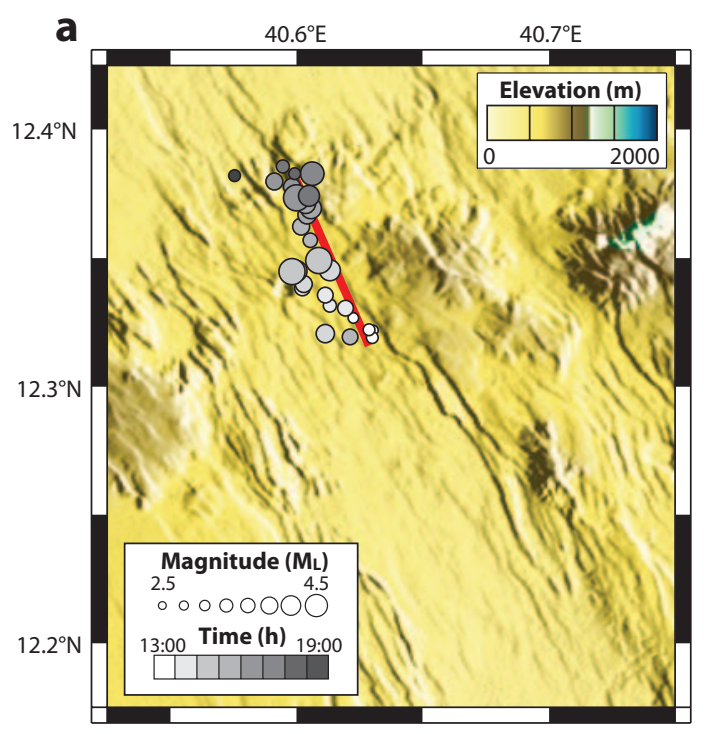

b
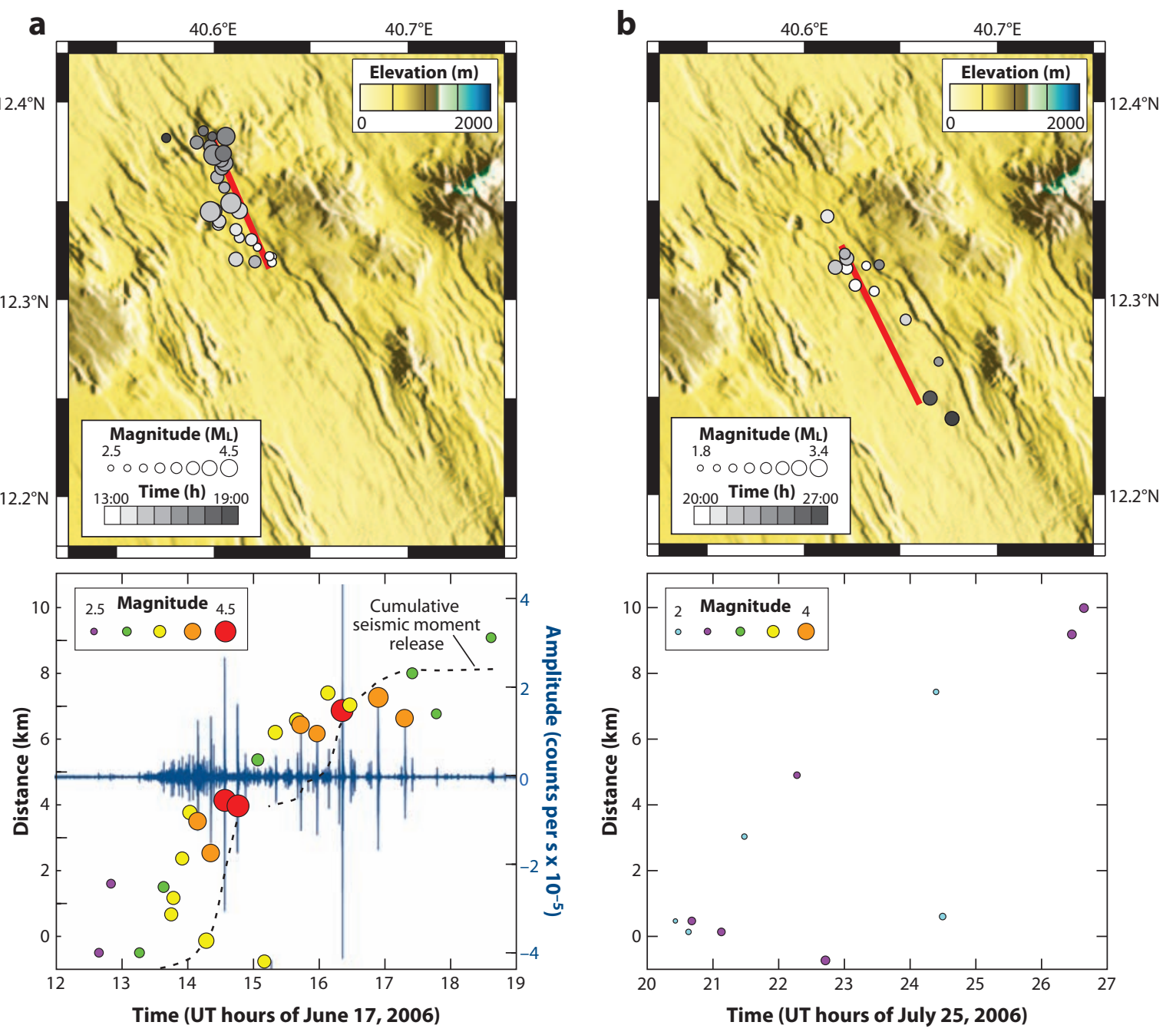

Figure 9

Examples of earthquake patterns associated with two major dike intrusions in June and July 2006 (after Keir et al. 2009). (a) Seismicity associated with the June 17, 2006 dike intrusion in the Dabbahu segment. (Upper panel) Earthquake hypocenters plotted on topography with shading and size indicating earthquake time and magnitude, respectively. Red bar indicates the dike position inferred from models of InSAR data. (Lower panel) Graph showing time on the $\mathrm{x}$ axis and on the y axis: (1) position of earthquakes projected onto an alongaxis profile defined by the position of the June 17, 2006, dike (earthquakes are colored and scaled by magnitude); (2) cumulative seismic moment release (dashed line); and (3) continuous, unfiltered, vertical component, velocity seismogram from station Abala located $\sim 160 \mathrm{~km}$ north-northwest of the activity. (b) As in panel $a$ but for the dike intrusion on July 25, 2006. However, in the lower panel, only position of earthquakes along the intruded dike is plotted against time.

subsided four days later. Numerous small spatter and scoria cones were arranged along the length of the N10W striking en echelon fissures. Fault scarps with fresh breaks and rock falls bordered the new flows. A'a and pahoehoe lavas were several meters thick in some areas (Yirgu 2007).

Interferograms indicate a dike intrusion accompanied the fissural eruption (Hamling et al. 2009); the dike intrusion probably occurred during the earthquake swarm preceding the curtain of fire episode. Hot spots and field observations of lava flows were located along the southern $5 \mathrm{~km}$ 
of the deformation field, implying that the whole dike did not rupture the surface. The best-fitting model of surface deformation suggests a dike with a maximum opening of $2.4 \mathrm{~m}$ and with normal faults that slip by no more than $0.7 \mathrm{~m}$ (Hamling et al. 2009) (Table 1). Assuming the eruption was 5-km long, 200-m across, and no more than 2-m thick, as estimated from field observations, the total erupted volume was only $3 \%$ of the total intruded volume (Hamling et al. 2009).

Dike Events 8-12: November 2007, March 2008, July 2008, October 2008, February 2009

Dike Event 8 initiated on November 11, 2007, at 16:04 with a tectonic earthquake along the fault system bounding the eastern flank of the rift (Belachew et al. 2009). Earthquakes occurred every few minutes until approximately 14:00 on November 13. Models of radar interferometry and GPS data indicate that this was a large-volume dike intrusion (Figure 4). A zone of up to $8.5 \mathrm{~cm}$ of subsidence at the northern end of the interpreted dike implies at least some of the magma may have been sourced from a shallow chamber (Hamling et al. 2009). The time-space relations of seismicity indicate that the swarm was in fact two separate dikes, with a gap of $\sim 6 \mathrm{~h}$ between the discrete dike intrusions (Belachew et al. 2009). The second migrating swarm extended $\sim 5 \mathrm{~km}$ south of the southern limit inferred from elastic-dislocation models of the interferograms and GPS vectors (Hamling et al. 2009, Belachew et al. 2009).

Seismicity patterns reveal Dike Event 9 was intruded from 03:38 on March 31 to approximately 05:00 on April 01, comprising two separate intrusions (Belachew et al. 2009). Maximum opening is approximately $1 \mathrm{~m}$ between 5 - and 9-km depth, consistent with seismicity patterns. Earthquakes associated with Dike Event 10 initiated at the segment center at 08:24 on July 9, 2008, and propagated southward to the termination of Dike 9 by 14:38 on July 10. Event 10 was a smallervolume intrusion, but its lateral extent may have been facilitated by the passage of Dikes 8 and 9.

Dikes 11 and 12 initiated near the segment center and propagated northward from the Ado'Ale volcanic complex. Seismicity associated with Dike Event 11 began at approximately 07:15 on October 17, 2008 and propagated northward from the segment center (Figure 4). Activity continued for nearly three more days (Belachew et al. 2009). Dike Event 12 initiated at 17:11 on February 11, 2009, near the segment center, with earthquake swarms migrating approximately two-thirds the length of Dike Event 11 during the next $6 \mathrm{~h}$ (Figure 5).

\section{Dike Event 13: June 2009 Fissural Eruption}

On June 29, 2009, the OMI instrument aboard NASA's EOS-Aura satellite detected a large $\mathrm{SO}_{2}$ cloud in southern Afar, as was seen in 2007 (S. Carn, personal communication). A field team reached the eruption site on July 4 and found a'a basalt flows approximately $2-3-\mathrm{m}$ thick sourced from fissures approximately 4-5-km long, lined by scoria ramparts 30-50-m high. Erupted lavas cover 2007 flows and are feldspar porphyritic basalt. Initial observations suggest that this eruption was slightly larger in volume than the August 2007 fissural eruption (Ferguson et al. 2010). As in the August 2007 fissural eruption, the July 2009 dike intrusion was largely aseismic.

\section{AFAR RIFTING CYCLE: INTERIM SYNTHESIS}

Observations from the Dabbahu-Manda Hararo segment of the southern Red Sea rift zone in Afar reveal the interplay between faulting and magmatism in space and time during one intense rifting episode as well as its relation to the time-averaged rift morphology. The combined data 
sets and the exposed rock record require multiple active magma reservoirs. The scale and pattern of faulting and magmatism are characteristic of earlier episodes in the Dabbahu-Manda Hararo segment, as recorded in the rock record and time-averaged topography (e.g., Figure 7). Similar patterns are also seen in the Alayta, Tat'Ale, and Erta'Ale magmatic segments of the Red Sea rift and the Asal-Ghoubbet segment of the Gulf of Aden rift (e.g., Barberi \& Varet 1977, Hayward \& Ebinger 1996, Rowland et al. 2007, Doubre et al. 2007a) (Figures 2 and 3). There are no historic records to document the repeat times between major rifting episodes, and local superstitions have prevented discussions of oral traditions. The Krafla rift segment experienced multiple fissural eruptions $\sim 250$ years prior to the onset of the major rifting episode in 1975 (Tryggvason 1994); repeat times in the more slowly extending Afar rift are probably longer (Figure 10).

\section{Magma Sources}

Combined geodetic, seismicity, and fault patterns map the temporal and spatial extent of dike passage, but the magma reservoirs feeding the dikes and volcanoes are more difficult to image. The time sequence of events and the composition of erupted lavas provide some clues (e.g., Gudmundsson 2006). Dike intrusions are commonly initiated by failure along the margins of magma chambers (e.g., Hill \& Prejean 2007, McLeod \& Tait 1999). The injection of hot basaltic magma to existing magma chambers increases liquid and gas pressure, potentially triggering failure over timescales dependent on the viscosity of the melt within the chamber (McLeod \& Tait 1999). Sanidine feldspar lathes in pumice erupted from the 2005 vent site show resorption, indicating that their growth was interrupted by heating prior to eruption (A. Philpott, personal communication). Laboratory models suggest that delays between magma replenishment and eruption for rhyolitic lavas are on the period of months to years (McLeod \& Tait 1999), arguing against an eruption triggered by dike heating 1-2 days before the eruption. Gab'ho volcano inflated during the year preceding onset of the rifting cycle, suggesting an earlier heating event.

Ayele et al. (2009) suggested that ground shaking associated with an eruption within the DVC destabilized a magma chamber beneath the AVC, triggering the release of plate boundary stress along the $\sim 65 \mathrm{~km}$-long segment. The migrating seismic swarms between September 14 and September 20 suggest magma movement within and/or between Dabbahu and Gab'ho volcanoes (Figure 6).

Multiple lines of evidence indicate that Dike Events 1-12 connect to one or more pressurized magma sources beneath the rift axis at the latitude of the AVC. Excluding the September 14-24 activity at the DVC, all the dike intrusions initiate near the center of the segment, beneath the rift axis topographic high marking the AVC (Keir et al. 2009, Hamling et al. 2009, Ayele et al. 2009, Belachew et al. 2009) (Figures 5 and 10). Dike Event 1 propagated northward, with greatest fault rupture along the eastern rift graben between 12.4 and 12.5 N (Ayele et al. 2009, Grandin et al. 2009) (Figure 5). The broad zone of uplift observed in both InSAR and GPS data prior to the June intrusion and the subsidence observed in November 2007 also point to a magma source beneath the AVC (Hamling et al. 2009).

How deep is the magma chamber near the center of the segment that feeds all but the premonitory dike intrusions? Models of the dike opening distribution along the length of the rift depend on assumptions regarding the distribution and depth of deep sources (e.g., Wright et al. 2006, Grandin et al. 2009). Grandin et al. (2009) demonstrated that a 10-km-deep source lies beneath $\sim 12.3 \mathrm{~N}$, which maximizes slip at this latitude and resolves an opening gap in the model of Wright et al. (2006). The geochemical signature of basalts erupted in 2007 indicates that some component of the magma evolved at depths of $5-7.5 \mathrm{~km}$, suggesting multiple magma reservoirs beneath the central segment (Ferguson et al. 2010). 

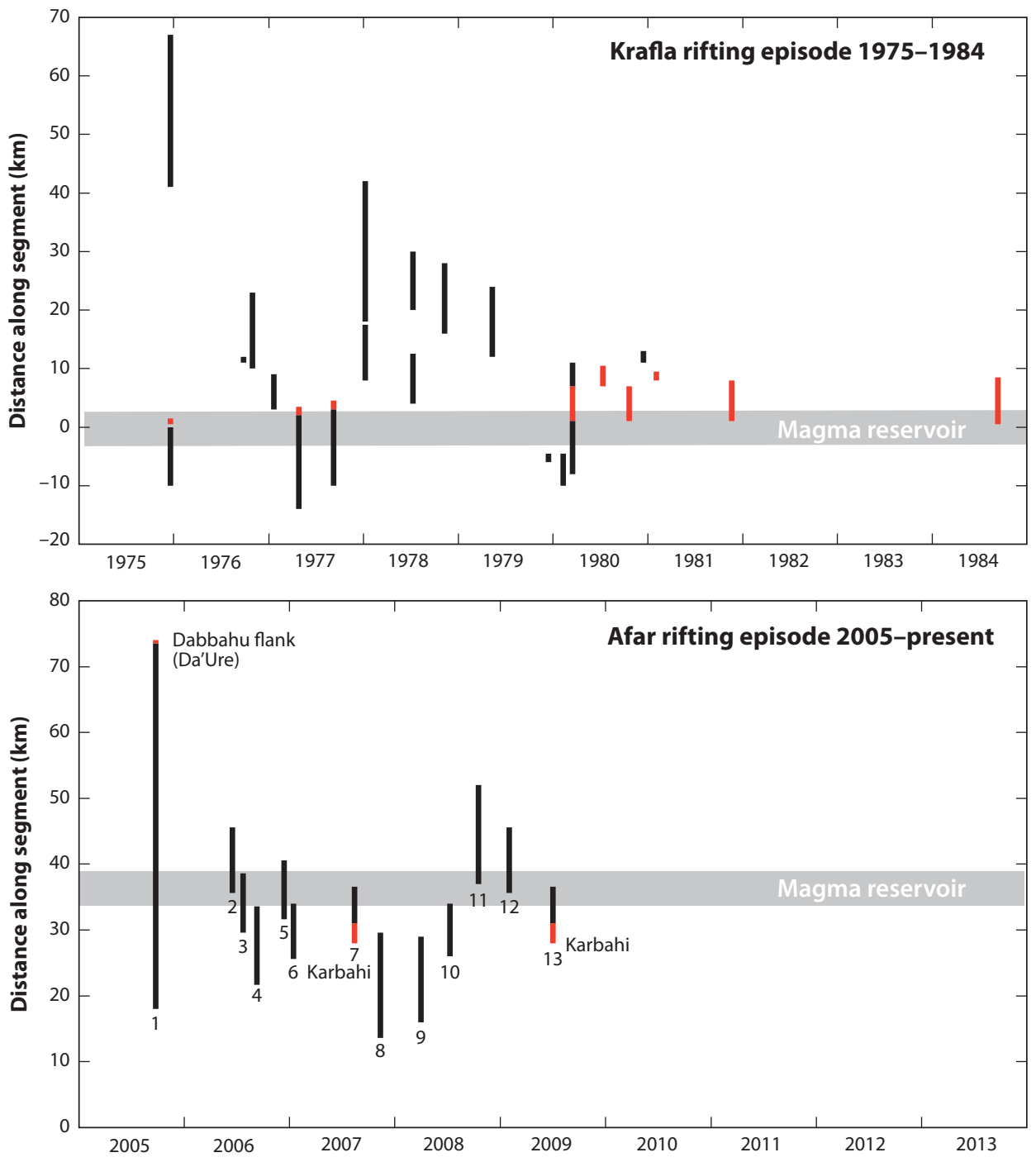

Figure 10

Time and space relations between dike intrusion and fissural eruption for the Dabbahu-Manda Hararo rift segment compared with the 9-year Krafla, Iceland, sequence. Vertical axis represents distance along the rift segment, black lines indicate the along-axis extent of discrete dike intrusions, and red lines denote dike intrusions with fissural eruptions. Proposed locations of the crustal magma reservoirs feeding the Dabbahu-Manda Hararo segment and Krafla reservoir feeding the Iceland segment are marked by gray lines (based on Einarsson 1991 and Hamling et al. 2009).

The central magmatic feeding system differs from mid-ocean ridge rifting episodes in the Krafla segment, Iceland, and Asal-Ghoubbet, Djibouti, where dikes were fed from shallow-topped magma reservoirs (2-4 km) near the center of the rift axis (e.g., Sigmundsson 2006, Doubre et al. 2007a). Postrifting geodetic data suggest a deeper source may underlie the Krafla volcano (de Zeeuw-van Dalfsen et al. 2004). These differences may relate to the relatively short time period since onset of seafloor spreading in the Dabbahu-Manda Hararo segment, which is underlain by 
thicker and mechanically stronger lithosphere than the more evolved Asal-Ghoubbet rift (Doubre et al. 2007b) and the long-lived seafloor spreading system in Iceland (e.g., Sigmundsson 2006).

\section{Along-Axis Ridge Segmentation Initiation and Maintenance}

The September 2005 volcanic eruption-dike intrusion sequence deduced from seismicity patterns, satellite geodesy, and field observations caused deformation along the length of a discrete tectonomagmatic segment delineated in earlier studies (Barberi \& Varet 1977, Hayward \& Ebinger 1996) (e.g., Figure 11). Rift opening accommodated by the initial dike intrusion was irregular along the length of the rift, with the largest opening in the northern half of the segment (Wright et al. 2006, Grandin et al. 2009) (Figure 11). Subsequent dike intrusions have occurred in the southern sections of the segment, suggesting they serve to equalize stress release along the length of the

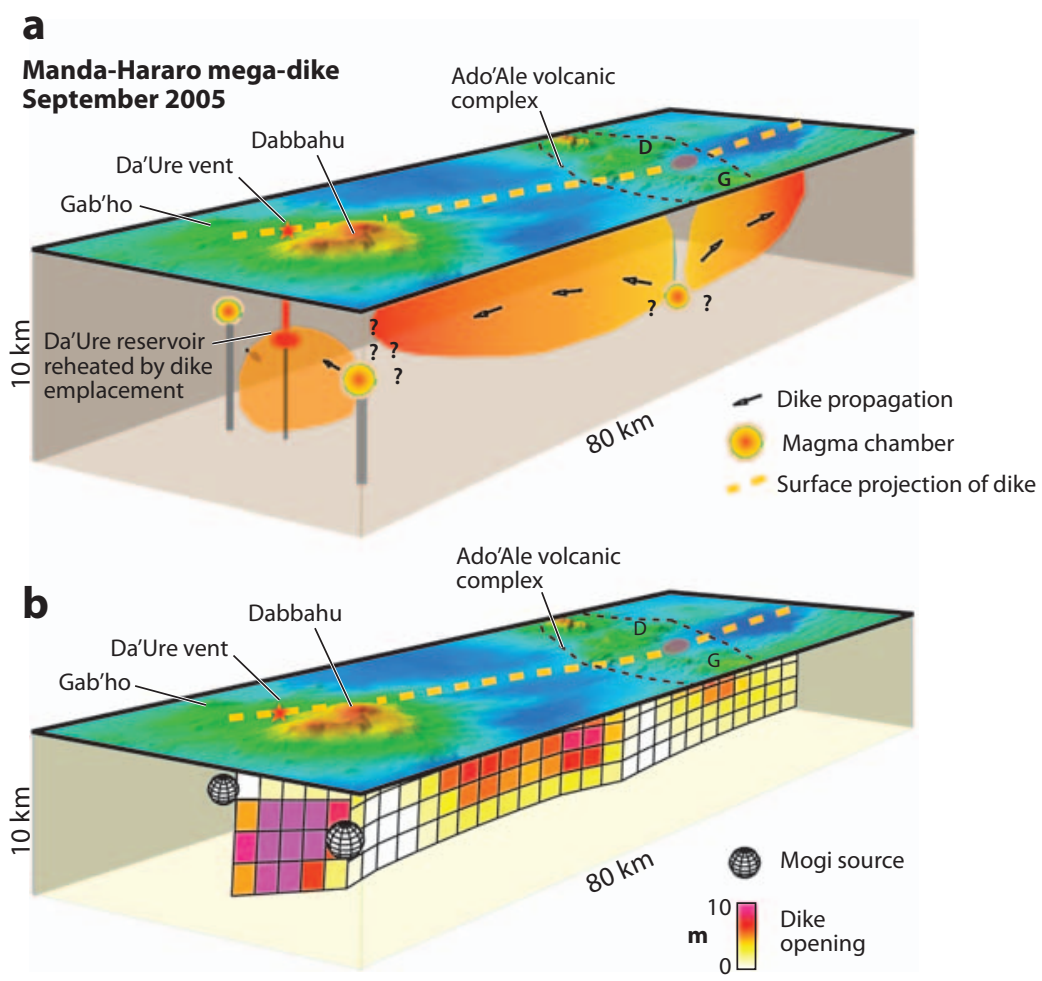

Figure 11

Scaled geological $(a)$ and rift opening model $(b)$ for the September 2005 event initiating the rifting cycle in the Dabbahu-Manda Hararo rift segment (after Ayele et al. 2009). Yellow dashed line indicates the surface trace of the dikes. (a) Surface topography with magma chambers and dikes inferred from seismicity and surface deformation patterns. Arrows indicate magma movement directions inferred from migrating earthquake swarms and postseismic deformation (Ayele et al. 2009, Ebinger et al. 2008). Diyilu (D) and Gommoyta (G) are the eastern and western sides, respectively, of a rifted silicic volcano in the AVC.

(b) Topography and model of dike opening that reproduces vertical and horizontal crustal movements determined from InSAR data, constrained by seismic observations. Spheres are Mogi sources that simulate magma pressure sources added to the dike opening to produce the observed surface deformation patterns (based on Ayele et al. 2009). 
segment (Hamling et al. 2009, Grandin et al. 2009). Distributed opening models indicate that the total volume intruded from Dike Events 2 through 8 is $25 \%$ of the September 2005 intrusion (Hamling et al. 2009).

Multiple dike intrusions sourced from one or more mid-segment magma chambers effectively maintain the along-axis segmentation pattern of this incipient seafloor spreading center. The complication to this pattern is the DVC at the northern end of the segment, which also sourced the dike(s). The Alayta segment to the north is offset to the east of the Dabbahu-Manda Hararo segment (Figures 2 and 3). This along-axis geometry places the northern tip of the Dabbahu segment against colder, thicker lithosphere, inhibiting the lateral dike propagation; in the absence of through-going transform faults, magma ponds in crustal reservoirs (e.g., Figures 2 and 11).

More than $90 \%$ of the plate opening during the first and subsequent dike intrusions was accommodated aseismically by the intrusion of magma, and seismic energy release during the interdike periods was minor $\left(M_{L}<3.9\right)$ (Ebinger et al. 2008, Keir et al. 2009, Belachew et al. 2009). Thus, the intense, short-period rifting episode shows an even greater percentage of aseismic deformation than the time-averaged slow-spreading ridge deformation deduced from a global synthesis (Solomon et al. 1988). Although crustal thickness is $16-18 \mathrm{~km}$ versus $8-10 \mathrm{~km}$ on slowspreading ridges, the process of plate boundary deformation is the same: magma sourced from chambers beneath segment centers and transported along-axis by dikes. Ongoing analyses of seismic, magneto-telluric, petrological, and geodetic data sets will image magma bodies and crust and upper mantle properties along and across this and adjoining rift sectors (e.g., Hammond et al. 2009, Guidarelli et al. 2009, Hautot et al. 2009), providing tests of the passive and active upwelling models for along-axis segmentation of mid-ocean ridges (e.g., Lin et al. 1990, Bonatti et al. 2003, Carbotte et al. 2006, Singh et al. 2006).

Tectono-magmatic segments with seismicity, structural, volcanic, and morphological patterns similar to the Dabbahu-Manda Hararo segment mark the locus of plate boundary deformation in all three rift arms of the Afar triple junction, suggesting that a centrally located along-axis magmatic plumbing system develops prior to continental rupture (e.g., Ebinger \& Casey 2001, Keir et al. 2006) (Figures 3 and 11).

\section{Implications for Creation of Rift Morphology}

The magnitude of fault slip, as deduced from remote imagery and from sparse field measurements (e.g., Figure 6), attests to the importance of dike intrusion to the development of rift zone geomorphology (e.g., Rubin \& Pollard 1988). Scarp heights of generally $<30 \mathrm{~m}$ demonstrate that fault reactivation occurs. If the distribution of brittle strain associated with this rifting episode is assumed to be typical for the segment over time and is the principal means by which these faults grow, then the minimum number of discrete rifting episodes required to account for the rift geomorphology can be estimated. For example, taking 2-3 $\mathrm{m}$ of vertical offset as a typical fault displacement per rifting episode, a scarp height of 30 m may represent up to 15 magmatic rifting cycles (e.g., Figure 8). We do not know the rate of topographic resurfacing by lava production, and we have yet to analyze a digital elevation model of sufficient resolution to capture adequately the relief across the rift. Accepting these qualifications, Rowland et al. (2007) made a crude estimate of the number of rifting cycles required to account for the rift by assuming an average fault spacing $(200 \mathrm{~m})$ and throw $(10 \mathrm{~m})$ across the 15 -km-wide segment. Less than 400 rifting episodes could account for the observed topography across the segment if a 5-km-wide swath is activated in any single rifting episode. Taking the $6 \mathrm{~m}$ of horizontal extension described for the 2005 intrusion as a representative value and bearing in mind the $\sim 50 \mathrm{~mm} \mathrm{year}^{-1}$ transient deformation signal seen at near-field GPS stations (Nooner et al. 2009, Bennati et al. 2009), we find that as few as one rifting 
episode approximately every 400 years is sufficient to accommodate the time-average opening rate of $16 \mathrm{~mm} \mathrm{year}^{-1}$ (Chu \& Gordon 1998): The topography of the Dabbahu rift segment may have developed in as little as $\sim 200 \mathrm{ka}$. Although we cannot discount the possibility that rift morphology includes a component of amagmatic faulting, the high fault-fracture density (Figure 8 $a$ ) and the common overprinting of fault-fracture arrays (Figure $8 \boldsymbol{b}$ ) suggest that reactivation of crustal-scale slip surfaces is not the principal means by which strain is accommodated in this rift system.

Elastic dislocation models and fault studies, however, provide few constraints on the deformation mechanisms within the lower crust. Stretched and intruded crust beneath the Afar depression is approximately half the thickness of crust beneath the uplifted plateau, and the active rift zones show an additional 20-30\% thinning (Hammond et al. 2009). Magma intrusion does not explain the crustal thinning seen in the tectonically active magmatic segments, suggesting ductile deformation also accompanies the dike intrusion and upper crustal faulting.

\section{Implications for the Close of the Rifting Episode}

A new dike intrusion and fissural eruption occurred in Afar during the preparation of this manuscript in July 2009. The remarkable similarities between the 1975-1984 Krafla rifting episode and the Dabbahu-Manda Hararo rifting episode indicate more dike intrusion events are likely (Figure 10). Of greater concern, the comparison indicates that more effusive volcanism is to follow. The ratio of eruptive to intrusive volume for the time period from September 2005 to July 2009 dike intrusion and fissural eruptions is 1:180, compared with the final Krafla ratio of 1:3 (Ferguson et al. 2010).

These findings show that episodic (approximate century interval), rapid opening of discrete rift segments is the primary mechanism of plate boundary deformation at the onset of seafloor spreading. The scale and intensity of crustal deformation as well as the volume of intrusive and extrusive magmatism provokes a re-evaluation of seismic and volcanic hazard in late-stage continental rifts; volcanoes are not the only "smoking guns" in Afar. Recognition that 65-km-long swathes of land could be sites of fissural eruptions during rifting episodes requires large-scale monitoring and the development of a new generation of hazard models for volcanic rifts (e.g., Yirgu et al. 2006, Hagos et al. 2006a, Ayele et al. 2009). International partnerships formed during the acquisition and interpretation of new date-constraining rates and scales of rift deformation strengthen the foundation for regional hazard mitigation initiatives.

\section{DISCLOSURE STATEMENT}

The authors are not aware of any affiliations, memberships, funding, or financial holdings that might be perceived as affecting the objectivity of this review.

\section{ACKNOWLEDGMENTS}

Without the assistance of so many Ethiopian and international scientists, none of the field data would have been acquired. We thank the Ethiopian Federal Government for providing helicopter support and the Afar Regional Government for invaluable assistance throughout all stages of the ongoing studies. Generous field and logistical contributions from Laikemariam Asfaw, Araya Asfaw, Asfawossen Asrat, Dereje Ayalew, Liz Baker, Manahloh Belachew, Laura Bennati, Juliet Biggs, Roger Buck, Eric Calais, Ellen Campbell, Dustin Coté, Getahun Demissie, John Elliott, Shimeles Fisseha, Ian Hamling, James Hammond, Sophie Hautot, Mike Kendall, Tesfaye Kidane, Elias Lewi, Carolina Pagli, Graham Stuart, Feleke Worku, Kathy Whaler, and 
Addishiwot Woldesenbet are much appreciated. Sophie Hautot and Barbara Hofmann produced the high-resolution digital elevation model constructed from SPOT imagery. Raphaël Grandin, Eric Jacques, and Geoff King shared data and work in progress. Seis-UK support from Alex Brisbourne and Anna Horleston and IRIS-Passcal support from Michael Fort and Eliana Arias-Dotson ensured the success of seismic studies. Alex Aronovitz and Clyde Brown assisted with seismic data analyses. The support of National Science Foundation grant EAR-0635789; NERC grants NE/D008611/1, NE/D01039X/1, NE/E007414/1, and NE/E013945/1 (D.K.); and Marsden Fund grant (J.R.) are gratefully acknowledged. This material is based on work supported in part by the National Science Foundation grants PHY-0552695 and PHY-0851243.

\section{LITERATURE CITED}

Abdallah A, Courtillot V, Kasser M, Le Dain A-Y, Lépine J-C, et al. 1979. Relevance of Afar seismicity and volcanism to the mechanics of accreting plate boundaries. Nature 282:17-23

Ayele A, Keir D, Ebinger CJ, Wright TJ, Stuart GW, et al. 2009. The September 2005 mega-dike emplacement in the Manda-Hararo (Afar) nascent oceanic rift. Geophys. Res. Lett. 36:L20306

Ayele A, Jacques E, Kassim M, Kidane T, Omar A, et al. 2007a. The volcano-seismic crisis in Afar, Ethiopia, starting September 2005. Earth Planet. Sci. Lett. 255:187-97

Ayele A, Kulhánek O. 1997. Spatial and temporal variation of the seismicity in the Horn of Africa from 1960 to 1993. Geophys. F. Int. 130:805-10

Ayele A, Stuart GW, Bastow ID, Keir D. 2007b. The August 2002 earthquake sequence in north Afar: insights into the neotectonics of the Danakil microplate. F. Afr. Earth Sci. 40:70-79

Barberi F, Varet J. 1977. Volcanism of Afar: small-scale plate tectonic implications. Geol. Soc. Am. Bull. $88: 1251-66$

Barisin I, Leprince S, Parsons B, Wright TJ. 2009. Surface displacements in the September 2005 Afar rifting event from satellite image matching: asymmetric uplift and faulting. Geophys. Res. Lett. 36:L07301

Bastow ID, Keir D, Daly E. 2010. The Ethiopian Afar Geoscientific Lithospheric Experiment (EAGLE): probing the transition from continental rifting to sea-floor spreading. Geol. Soc. Am. Spec. Publ. In press

Bastow ID, Nyblade AA, Stuart GW, Rooney TO, Benoit MH. 2008. Upper mantle seismic structure beneath the Ethiopian hot spot: rifting at the edge of the African low velocity anomaly. Geochem. Geophys. Geosyst. 9:Q12022

Beccaluva L, Bianchini G, Natali C, Siena F. 2009. Continental flood basalts and mantle plumes: a case study of the northern Ethiopian plateau. 7. Petrol. 50(7):1377-403

Behn M, Buck WR, Sacks S. 2006. Topographic controls on dike injection in volcanic rift zones. Earth Planet. Sci. Lett. 246:188-96

Belachew M, Ebinger C, Keir DB, Coté D, Ayele A. 2009. Comparison of dike intrusions in Afar: seismic perspective for source and extent. Eos Trans. AGU 90(52), Fall Meet. Suppl., Abstr. T31B-1811

Bennati L, Calais E, Freed AM, Hamling I, Wright TJ, et al. 2009. Post-rifting relaxation processes in the Afar region (Ethiopia) from geodetic measurements and numerical modelling. Eos. Trans. AGU 90(52), Fall Meet. Suppl., Abstr. T31B-1814

Benoit MH, Nyblade AA, VanDecar JC. 2006. Upper mantle P wave speed variations beneath Ethiopia and the origin of the Afar hot spot. Geology 34:329-32

Berckhemer HB, Baier H, Bartelson A, Behle H, Bürkhardt H, et al. 1975. Deep seismic soundings of the Afar region and on the highland of Ethiopia. In Afar Between Continental and Oceanic Rifting, ed. A Pilger, A Rosler, pp. 89-107. Stuttgart: Schweizerbart

Bjornsson A, Saemundsson K, Einarsson P, Tryggvason E, Gronvald K. 1977. Current rifting episode in North Iceland. Nature 266:318-23

Bonatti E, Ligi M, Brunelli D, Cipriani A, Fabretti P, et al. 2003. Mantle thermal pulses below the Mid-Atlantic Ridge and temporal variations in the formation of oceanic lithosphere. Nature 423:499-505

Bonatti E. 1985. Punctiform initiation of seafloor spreading in the Red Sea during transition from a continental to an oceanic rift. Nature 316:33-37 
Brandsdottir B, Einarsson P. 1979. Seismic activity associated with the September 1977 deflation of Krafla volcano in North-Eastern Iceland. 7. Volcanol. Geotherm. Res. 6:197-212

Buck WR. 2004. Consequences of asthenospheric variability on continental rifting. In Rheology and Deformation of the Lithosphere at Continental Margins, eds. GD Karner, B Taylor, N Driscoll, B Kohlstedt, pp. 92-137. New York: Columbia Univ. Press

Buck WR, Einarsson P, Brandsdóttir B. 2006. Tectonic stress and magma chamber size as controls on dike propagation: constraints from the 1975-1984 Krafla rifting episode. F. Geophys. Res. 111:B12404

Calais E, d'Oreye N, Albaric J, Deschamps A, Delvaux D, et al. 2008. Strain accommodation by dyking in a youthful continental rift, East Africa. Nature 456:783-87

Canales J-P, Nedimovic MR, Kent GM, Carbotte SM, Detrick RS. 2006. Seismic reflection images of a near-axis melt sill within the lower crust at the Juan de Fuca ridge. Nature 460:89-93

Carbotte SM, Detrick RS, Harding RS, Canales JP, BabcockJ, et al. 2006. Rift topography linked to magmatism at the intermediate spreading Juan de Fuca Ridge. Geology 34:209-12

Cattin R, Doubre C, de Chabalier J-B, King GCP, Vigny C, et al. 2005. Numerical modelling of quaternary deformation and post-seismic displacement in the Asal-Ghoubbet rift (Djibouti, Africa). Earth Planet. Sci. Lett. 239:352-67

Chu D, Gordon R. 1998. Evidence for motion beween Nubia and Somalia along the southwest Indian ridge. Nature 398:64-67

Coté DM, Kulpinski K, Ebinger CJ, Keir D, Ayele A. 2009. Testing models of dike intrusion during rifting episodes: the role of heating in triggering earthquakes in Afar. Eos Trans. AGU 90(52), Fall Meet. Suppl., Abstr. T31B-1820

Courtillot V, Galdeano A, Le Mouël J-L. 1980. Propagation of an accreting plate boundary: a discussion of new aeromagnetic data in the Gulf of Tadjurah and southern Afar. Earth Planet. Sci. Lett. 47:144-60

Cowie PA, Scholz CH, Edwards M, Malinverno A. 1993. Fault strain and seismic coupling on mid-ocean ridges. 7. Geophys. Res. 98(B10):17911-20

Dauteuil O, Angelier J, Bergerat F, Verrier S, Villemin T. 2001. Deformation partitioning inside a fissure swarm of the northern Icelandic rift. 7. Struct. Geol. 23:1359-72

Debayle E, Lévêque JJ, Cara M. 2001. Seismic evidence for a deeply rooted low velocity anomaly in the upper mantle beneath the northeastern Afro/Arabian continent. Earth Planet. Sci. Lett. 193(3-4):369-82

De Chabalier JB, Avouac J-P. 1994. Kinematics of the Asal rift (Djibouti) determined from the deformation of Fieale volcano. Science 265:1677-81

Delaney J, Kelley DS, Lilley MD, Butterfield DA, Baross JA, et al. 1998. The quantum event of oceanic crustal accretion: impacts of diking at Mid-Ocean ridges. Science 281:222-30

de Zeeuw-van Dalfsen E, Pedersen R, Sigmundsson F, Pagli C. 2004. Satellite radar interferometry suggests deep accumulation of magma near the crust-mantle boundary beneath the Krafla volcanic system, Iceland. Geophys. Res. Lett. 31:L14610

Doubre C, Manighetti I, Dorbath L, Dorbath C, Jacques E, Delmond J-C. 2007a. Crustal structure and magmato-tectonic processes in an active rift (Asal-Ghoubbet, Afar, East Africa): 1. Insights from a 5-month seismological experiment. 7. Geophys. Res. 112:B5

Doubre C, Manighetti I, Dorbath L, Dorbath C, Bertil D, Delmond J-C. 2007b. Crustal structure and magmato-tectonic processes in an active rift (Asal-Ghoubbet, Afar, East Africa): 2. Insights from the 23-year recording of seismicity since the last event. 7. Geophys. Res. 112:B05406

Dugda M, Nyblade AA. 2006. New constraints on crustal structure beneath eastern Afar from analysis of receiver functions and surface wave dispersion in Djibouti. See Yirgu et al. 2006, pp. 239-51

Dugda M, Nyblade AA, Julia J. 2007. Thin lithosphere beneath Ethiopia and Djibouti revealed by a joint inversion of Rayleigh wave group velocities and receiver functions. F. Geophys. Res. 112:B08305

Dziak RP, Smith DK, Bohnenstiehl DR, Fox CG, Desbruyères D, et al. 2004. Evidence of a recent magma dike intrusion at the slow spreading Lucky Strike segment, Mid-Atlantic Ridge. 7. Geophys. Res. 109:B12102

Dziak RP, Bohnenstiehl DR, Cowen JP, Baker ET, Rubin KH, et al. 2007. Rapid dike emplacement leads to eruptions and hydrothermal plume release during sea-floor spreading events. Geology 35:579-82

Dziak RP, Bohnenstiehl DR, Matsumoto H, Fowler MJ, Haxel JH, et al. 2009. January 2006 seafloor-spreading event at 9050 'N, East Pacific Rise: ridge dike intrusion and transform fault interactions from regional hydroacoustic data. Geochem. Geophys. Geosyst. 10:Q06T06 
Eagles G, Gloaguen R, Ebinger CJ. 2002. Kinematics of the Danakil microplate. Earth Planet. Sci. Lett. 203(2):607-20

Ebinger CJ, Casey M. 2001. Continental break-up in magmatic provinces: an Ethiopian example. Geology 29:527-30

Ebinger CJ, Sleep NH. 1998. Cenozoic magmatism in central and east Africa resulting from impact of one large plume. Nature 395:788-91

Ebinger CJ, Keir D, Ayele A, Calais E, Wright TJ, et al. 2008. Capturing magma intrusion and faulting process during continental rupture: seismicity of the Dabbahu (Afar) rift. Geophys. 7. Int. 174:1138-52

Einarsson P. 1991. The Krafla rifting episode 1975-1989. In Náttúra Myvatns, (The Nature of Lake Myvatn), ed. A Gardarsson, Á Einarsson, pp. 97-139. Reykjavik: Icelandic Nat. Sci. Soc.

Einarsson P, Brandsdóttir B. 1980. Seismological evidence for lateral magma intrusion during the July 1978 deflation of the Krafla volcano in NE-Iceland. Tech. Rep. RH79-9, Sci. Inst. Univ. Iceland, Reykjavik

Evans B, Bernabé Y, Hirth G. 2004. Relations among porosity, permeability, and deformation in rocks at high temperatures. In Rheology and Deformation of the Lithoshpere at Continental Margins, ed. GD Karner, B Taylor, NW Driscoll, D Kohlstedt, pp. 311-40. New York: Columbia Univ. Press

Ferguson DJ, Barnie TD, Pyle DM, Oppenheimer C, Yirgu G, et al. 2010. Recent rift related volcanism in Afar, Ethiopia. Earth Planet. Sci. Lett. In press, doi:10.1016/j.epsl.2010.02.010

Fialko YA, Rubin AM. 1998. Thermodynamics of lateral dike propagation: implications for crustal accretion at slow spreading mid-ocean ridges. 7. Geophys. Res. 103(B2):2501-14

Field L, Blundy J, Yirgu G. 2008. The magmatic evolution of Dabbahu volcano, Afar, Ethiopia. Eos Trans. AGU 89(53), Fall Meet. Suppl., Abstr. V21B-2103

Fox CG, Chadwick WW Jr, Embley RW. 2001. Direct observation of a submarine volcanic eruption from a sea-floor instrument caught in a lava flow. Nature 412:727-29

Gouin, P. 1979. Earthquake History of Ethiopia and the Horn of Africa. Ottawa, Can.: IDRC. 258 pp.

Grandin R, Socquet A, Binet R, Klinger Y, Jacques E, et al. 2009. September 2005 Manda Hararo-Dabbahu rifting event, Afar (Ethiopia): constraints provided by geodetic data. F. Geophys. Res. 114:B08404

Gresta S, Patanè D, Daniel A, Zan L, Carletti A, Befekadu O. 1997. Seismological evidences of active faulting in the Tendaho rift (Afar triangle, Ethiopia). Pure Appl. Geophys. 149:357-74

Guidarelli M, Stuart GW, Hammond JOS, Kendall J-M, Ebinger CJ. 2009. Crustal structure across Afar, Ethiopia, from surface wave tomography. Eos Trans. AGU 90(52), Fall Meet. Suppl., Abstr. T31B-1809

Gudmundsson A. 2006. How local stresses control magma-chamber ruptures, dike injections, and eruptions in composite volcanoes. Earth Sci. Rev. 79:1-31

Hagos L, Arvidsson R, Roberts R. 2006a. Application of the spatially smoothed seismicity and Monte Carlo methods to estimate the seismic hazard of Eritrea and the surrounding region. Nat. Hazards 39:395-418

Hagos L, Shomali H, Roberts R. 2006b. Re-evaluation of focal depths and source mechanisms of selected earthquakes in the Afar depression. Geophys. F. Int. 167:297-308

Hamling IJ, Ayele A, Bennati L, Calais E, Ebinger CJ, et al. 2009. Geodetic observations of the ongoing Dabbahu rifting episode: new dyke intrusions in 2006 and 2007. Geophys. F. Int. 178:989-1003

Hammond JOS, Kendall JM, Stuart GW, Ebinger CJ. 2009. Seismic imaging of the crust and upper mantle beneath Afar, Ethiopia. Eos Trans. AGU 90(52), Fall Meet. Suppl., Abstr. T31B-1808

Hautot S, Whaler KA, Desissa M, Dawes G, Fisseha S, Johnson N. 2009. 3-D conductivity structure of an active magmatic segment associated with the final stage of continental break-up: Afar, Ethiopia. Eos Trans. $A G U$ 90(52), Fall Meet. Suppl., Abstr. T43F-07

Hayward NJ, Ebinger CJ. 1996. Variations in the along-axis segmentation of the Afar rift system. Tectonics $15: 244-57$

Heki K, Foulger G, Julian B, Jahn C-H. 1993. Plate dynamics near divergent boundaries: geophysical implications of post-rifting crustal deformation in NE Iceland. 7. Geophys. Res. 98:14279-97

Hill DP, Prejean S. 2007. Dynamic triggering. In Treatise on Geophysics: Earthquake Seismology, ed. H Kanamori, 4:257-91. Amsterdam: Elsevier

Hofstetter R, Beyth M. 2003. The Afar Depression: interpretation of the 1960-2000 earthquakes. Geophys. $\mathcal{F}$. Int. 155:715-32 
Hofton MA, Foulger GR. 1996. Postrifting anelastic deformation around the spreading plate boundary, north Iceland 1. Modeling of the 1987-1992 deformation field using a viscoelastic Earth structure. 7. Geophys. Res. 101(B11):25403-21

Holtzman B, Kohlstedt D, Zimmerman ME, Heidelbach F, Hiraga T, Hustoft T. 2003. Melt segregation and strain partitioning: implications for seismic anisotropy. Science 29:1227-30

Jacques E, Ruegg J-C, Lépine J-C, Tapponnier P, King GCP, Omar A. 1999. Relocation of M > 3 events of the 1989 Dobi sequence in Afar: evidence for earthquake migration. Geophys. 7. Int. 138:447-69

Kebede F, Kulhánek O. 1994. Spatial and temporal variations of $b$-values along the East African rift system and the southern Red Sea. Phys. Earth Planet. Inter. 83:249-64

Keir D, Ebinger CJ, Stuart GW, Daly E, Ayele A. 2006. Strain accommodation by magmatism and faulting at continental breakup: seismicity of the northern Ethiopian rift. 7. Geophys. Res. 111:B05314

Keir D, Ayele A, Calais E, Hamling IJ, Ebinger CJ, et al. 2009. Evidence for focused magmatic accretion at segment centers from lateral dike injections captured beneath the Red Sea rift in Afar. Geology 37:59-62

Kelemen P, Hirth G, Shimizu N, Spiegelman M, Dick HJB. 1997. A review of melt migration processes in the adiabatically upwelling mantle beneath oceanic spreading ridges. Philos. Trans. R. Soc. London Ser. A 355:283-318

Kendall J-M, Pilidou S, Keir D, Bastow ID, Stuart GW, Ayele A. 2006. Mantle upwellings, melt migration and the rifting of Africa: insights from seismic anisotropy. See Yirgu et al. 2006, pp. 55-72

Keranen K, Klemperer S, Julia J, Lawrence J, Nyblade AA. 2009. Lower crustal velocity across Ethiopia: Is the Main Ethiopian Rift a narrow rift in a hot craton? Geochem. Geophys. Geosyst. 10:Q0AB01

Kidane T, Courtillot V, Manighetti I, Audin L, Lahitte P, et al. 2003. New paleomagnetic and geochronological results from Ethiopian Afar: block rotations linked to rift overlap and propagation and determination of a 2 Ma reference pole for stable Africa. 7. Geophys. Res. 108(B2):2102

Lahitte P, Gillot P-Y, Kidane T, Courtillot V, Abebe B. 2003. New age constraints on the timing of volcanism in central Afar, in the presence of propagating rifts. F. Geophys. Res. 108(B2):2123

Lin J, Purdy GM, Schouten H. 1990. Evidence from gravity data for focused magmatic accretion along the Mid-Atlantic Ridge. Nature 344:627-32

Macdonald KC, Fox PJ, Perram L. 1998. A new view of the mid-ocean ridge from the behaviour of ridge-axis discontinuities. Nature 335:217-25

McKenzie DP, Davies D, Molnar P. 1970. Plate tectonics of the Red Sea and East Africa. Nature 226:243-48

McLeod P, Tait S. 1999. The growth of dikes from magma chambers. F. Volcanol. Geotherm. Res. 91:231-45

Maguire PKH, Keller G, Klemperer S, Mackenzie G, Harder S, et al. 2006. Crustal structure of the northern Main Ethiopian Rift from the EAGLE controlled-source survey; a snapshot of incipient lithospheric break-up. See Yirgu et al. 2006, pp. 271-93

Makris J, Ginzburg A. 1987. The Afar Depression: transition between continental rifting and sea floor spreading. Tectonophysics 141:199-214

Manighetti I, Tapponnier P, Courtillot V, Gruszow S, Gillot P-Y. 1997. Propagation of rifting along the Arabia-Somalia plate boundary: the gulfs of Aden and Tadjoura. 7. Geophys. Res. 102(B2):2681-710

Massonnet D, Feigl KL. 1995. Discrimination of geophysical phenomena in satellite radar interferograms. Geophys. Res. Lett. 22:1537-40

Mogi K. 1958. Relations between the eruptions of various volcanoes and the deformations of the ground surfaces around them. Bull. Earthq. Res. Inst. 239:352-67

Montelli R, Nolet G, Dahlen FA, Masters G, Engdahl ER, Hung S-H. 2004. Finite-frequency tomography reveals a variety of plumes in the mantle. Science 303:338-43

Nooner S, Bennati L, Calais E, Hamling IJ, Wright TJ, et al. 2009. Post-rifting relaxation in the Afar region, Ethiopia. Geophys. Res. Lett. 36:L21308

Ogubazghi G, Ghebreab W, Havskov J. 2004. Some features of the 1993 Bada earthquake swarm of southeastern Eritrea. 7. Afr. Earth Sci. 38:135-43

Okada Y. 1985. Surface deformation due to shear and tensile faults in a half-space. Bull. Seismol. Soc. Am. $75: 1135-54$

Oppenheimer C, Francis P. 1998. Implications of longeval lava lakes for geomorphological and plutonic processes at Erta'Ale volcano, north Afar. 7. Volcanol. Geotherm. Res. 80:101-11 
Pagli C, Wright TJ, Ebinger CJ, Barnie TD, Ayele A. 2009. Inflate, pause, erupt, recharge: the 2008 Alu eruption in the Erta 'Ale volcanic system (Ethiopia). Eos Trans. AGU 90(52), Fall Meet. Suppl., Abstr. T31B-1813

Pollitz F, Sacks S. 1996. Viscosity structure beneath northeast Iceland. F. Geophys. Res. 101(B8):17771-93

Pollitz F, Sacks S. 2002. Stress triggering of the 1999 Hector Mine earthquake by transient deformation following the 1992 Landers earthquake. Bull. Seismol. Soc. Am. 92:1487-96

Rivalta E, Segall P. 2008. Magma compressibility and the missing source for some dike intrusions. Geophys. Res. Lett. 35:L04306

Roman DC, Cashman KV. 2006. The origin of volcano-tectonic earthquake swarms. Geology 34:457-60

Rowland JV, Baker E, Ebinger CJ, Keir D, Kidane T, et al. 2007. Fault growth at a nascent slow spreading ridge: 2005 Dabbahu rifting episode, Afar. Geophys. F. Int. 171:1226-46

Rubin A. 1995. Propagation of magma-filled cracks. Annu. Rev. Earth Planet. Sci. 23:287-336

Rubin A, Pollard DD. 1988. Dike-induced faulting in rift zones in Iceland and Afar. Geology 16:413-17

Rubin AM, Gillard DD. 1998. Dike-induced earthquakes: theoretical considerations. 7. Geophys. Res. 103:10017-30

Sigmundsson F. 2006. Iceland Geodynamics: Crustal Deformation and Divergent Plate Tectonics. Berlin: SpringerVerlag. 228 pp.

Singh SC, et al. 2006. Discovery of a magma chamber and faults beneath a Mid-Atlantic Ridge hydrothermal field. Nature 442:1029-32

Solomon S, Huang P, Meinke L. 1988. The seismic moment budget of slowly spreading ridges. Nature 334:58-60

Souriot Th, Brun J-P. 1992. Faulting and block rotation in the Afar triangle, East Africa: the Danakil "crankarm" model. Geology 20:911-14

Stuart GW, Bastow ID, Ebinger CJ. 2006. Crustal structure of the northern Main Ethiopian Rift from receiver function studies. See Yirgu et al. 2006, pp. 253-68

Thatcher W, Hill DP. 1995. A simple model for the fault-generated morphology of slow-spreading midoceanic ridges. F. Geophys. Res. 100:561-70

Tolstoy M, Cowen JP, Baker ET, Fornari DJ, Rubin KH, et al. 2006. A sea-floor spreading events captured by seismometers. Science 314:1920-22

Tolstoy M, Bohnenstiehl DR, Edwards MH. 2001. Seismic character of volcanic activity at the ultraslowspreading Gakkel Ridge. Geology 29:1139-42

Tryggvason E. 1994. Surface deformation at the Krafla volcano, North Iceland 1982-1992. Bull. Volcanol. 56:98-107

Tucholke BE, Lin J. 1994. A geological model for the structure of ridge segments in slow spreading ocean crust. F. Geophys. Res. 99:11937-58

Van Avendonk HJA, Harding AJ, Orcutt JA, McClain JS. 2001. Contrast in crustal structure across the Clipperton transform fault from travel time tomography. 7. Geophys. Res. 106:10961-81

Vigny C, Huchon P, Ruegg J-C, Khanbari K, Asfaw LM. 2006. 25 years of geodetic measurements along the Tadjura-Asal rift system, Djibouti East Africa. 7. Geophys. Res. 111:B02402

Wolfenden E, Ebinger CJ, Yirgu G, Renne P, Kelley SP. 2005. Evolution of the southern Red Sea rift: birth of a magmatic margin. Geol. Soc. Am. Bull. 117:846-64

Wright TJ, Ebinger CJ, Biggs J, Ayele A, Yirgu G, et al. 2006. Magma maintained rift segmentation at continental rupture in the 2005 Afar dyking episode. Nature 442:291-94

Wright TJ, Parsons BE, Lu Z. 2004. Towards mapping surface deformation in three dimensions using InSAR. Geophys. Res. Lett. 31:L01607

Yirgu G. 2007. The August 2007 fissure eruption on the Dabbabu rift segment. Presented at Active Volcanism Cont. Rift. Conf., ECGS Workshop, 26th, Luxembourg

Yirgu G, Ayele A, Ayalew D. 2006. Recent seismo-volcanic crisis in northern Afar, Ethiopia. Eos Trans. AGU 87:328-29

Yirgu G, Ebinger CJ, Maguire PKH, eds. 2006. The Afar Volcanic Province within the East African Rift System. Vol. 259. London: Geol. Soc. London Spec. Publ. 
Annual Review

of Earth and

Planetary Sciences

Volume 38, 2010

\section{Contents}

Frontispiece

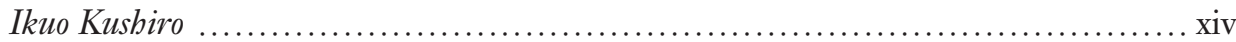

Toward the Development of "Magmatology"

Ikuo Kushiro ...................................................... 1

Nature and Climate Effects of Individual Tropospheric Aerosol

Particles

Mihály Pósfai and Peter R. Buseck

The Hellenic Subduction System: High-Pressure Metamorphism,

Exhumation, Normal Faulting, and Large-Scale Extension

Uwe Ring, fohannes Glodny, Thomas Will, and Stuart Thomson

Orographic Controls on Climate and Paleoclimate of Asia: Thermal

and Mechanical Roles for the Tibetan Plateau

Peter Molnar, William R. Boos, and David S. Battisti

Lessons Learned from the 2004 Sumatra-Andaman

Megathrust Rupture

Peter Shearer and Roland Bürgmann

Oceanic Island Basalts and Mantle Plumes: The Geochemical

Perspective

William M. White

Isoscapes: Spatial Pattern in Isotopic Biogeochemistry

Gabriel 7. Bowen

The Origin(s) of Whales

Mark D. Uhen

Frictional Melting Processes in Planetary Materials:

From Hypervelocity Impact to Earthquakes

John G. Spray

The Late Devonian Gogo Formation Lägerstatte of Western Australia:

Exceptional Early Vertebrate Preservation and Diversity

John A. Long and Kate Trinajstic 
Booming Sand Dunes

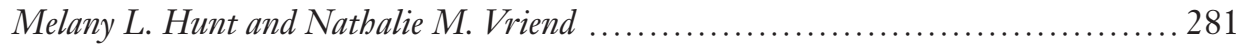

The Formation of Martian River Valleys by Impacts

Owen B. Toon, Teresa Segura, and Kevin Zahnle

The Miocene-to-Present Kinematic Evolution of the Eastern

Mediterranean and Middle East and Its Implications for Dynamics

Xavier Le Pichon and Corné Kreemer.

Oblique, High-Angle, Listric-Reverse Faulting and Associated

Development of Strain: The Wenchuan Earthquake of May 12, 2008, Sichuan, China

Pei-Zhen Zhang, Xue-ze Wen, Zheng-Kang Shen, and fiu-bui Chen

Composition, Structure, Dynamics, and Evolution of Saturn's Rings

Larry W. Esposito ....................................................... 38

Late Neogene Erosion of the Alps: A Climate Driver?

Sean D. Willett

Length and Timescales of Rift Faulting and Magma Intrusion:

The Afar Rifting Cycle from 2005 to Present

Cynthia Ebinger, Atalay Ayele, Derek Keir, Fulie Rowland, Gezahegn Yirgu,

Tim Wright, Manablob Belachew, and Ian Hamling ....

Glacial Earthquakes in Greenland and Antarctica

Meredith Nettles and Göran Ekström

Forming Planetesimals in Solar and Extrasolar Nebulae

E. Chiang and A.N. Youdin ....

Placoderms (Armored Fish): Dominant Vertebrates of the Devonian Period

Gavin C. Young......

The Lithosphere-Asthenosphere Boundary

Karen M. Fischer, Heather A. Ford, David L. Abt, and Catherine A. Rychert..... 551

\section{Indexes}

Cumulative Index of Contributing Authors, Volumes 28-38 ..................... 577

Cumulative Index of Chapter Titles, Volumes 28-38 .......................... 581

\section{Errata}

An online log of corrections to Annual Review of Earth and Planetary Sciences articles may be found at http://earth.annualreviews.org 